\title{
e An Updated Review of the Diagnostic Utility of Cervical Facet Joint Injections
}

Frank J.E. Falco, MD¹, Sukdeb Datta, MD², Laxmaiah Manchikanti, MD³, Nalini Sehgal, MD, Stephanie Geffert, MLIS', Vijay Singh, MD${ }^{5}$, Howard S. Smith, MD', and Mark V. Boswell, MD, PhD ${ }^{7}$

From: ${ }^{1}$ Mid Atlantic Spine \& Pain Physicians of Newark, Newark, DE; and Temple University Hospital, Philadelphia, PA; ${ }^{2}$ Laser Spine \& Pain Institute, and Mount Sinai School of Medicine, New York, NY; ${ }^{3}$ Pain Management Center of Paducah, Paducah,

$\mathrm{KY}$; and 3 University of Louisville, Louisville, KY; ${ }^{4}$ University of Wisconsin School of Medicine and Public Health, Madison, WI; ${ }^{5}$ Spine Pain Diagnostics

Associates, Niagara, WI

${ }^{6}$ Albany Medical College, Albany, New York; and ${ }^{87}$ Department of Anesthesiology and Perioperative Medicine, University of Louisville, Louisville, KY

Additional author affiliation information on Page E829

Address Correspondence: Sukdeb Datta, MD 90 Park Avenue, Suite 1700 New York, NY 10016 E-mail: sdattamd@gmail.com

Disclaimer: There was no external funding in the preparation of this manuscript.

Conflict of interest: None. Conflict of Interest:

Dr. Datta receives research support from Sucampo Pharmaceuticals and an honorarium from Smith

and Nephew Dr. Falco is a Consultant for St. Jude Medica Inc. and Joimax Inc.

Manuscript received: 10/01/2012 Accepted for publication: 10/12/2012

Free full manuscript: www.pain physicianjournal.com
Background: Chronic persistent neck pain with or without upper extremity pain is common in the general adult population with a prevalence of $48 \%$ for women and $38 \%$ for men, with persistent complaints in $22 \%$ of women and $16 \%$ of men. Multiple modalities of treatment are exploding in managing chronic neck pain along with increasing prevalence. However, there is a paucity of evidence for all modalities of treatments in managing chronic neck pain. Controlled studies have supported the existence of cervical facet or zygapophysial joint pain in $36 \%$ to $60 \%$ in heterogenous population of these patients. However, these studies also have shown false-positive results in $27 \%$ to $63 \%$ of patients with a single diagnostic block.

Study Design: A systematic review of diagnostic cervical facet joint nerve blocks.

Objective: To evaluate and update the accuracy of diagnostic facet joint nerve blocks in the diagnosis of facet joint pain.

Methods: A methodological quality assessment of included studies was performed using Quality Appraisal of Reliability Studies (QAREL). Only diagnostic accuracy studies meeting at least 50\% of the designated inclusion criteria were utilized for analysis. Studies scoring less than $50 \%$ are presented descriptively and critically analyzed.

The level of evidence was classified as good, fair, and limited or poor based on the quality of evidence developed by the United States Preventive Services Task Force (USPSTF).

Data sources included relevant literature identified through searches of PubMed and EMBASE from 1966 to June 2012, and manual searches of the bibliographies of known primary and review articles.

Results: Overall, a total of 26 manuscripts were considered for diagnostic accuracy evaluation and 9 manuscripts for studies evaluating various factors influencing the diagnostic validity of facet joint interventions. Based on 9 studies meeting the inclusion criteria utilizing $75 \%$ to $100 \%$ pain relief as the criterion standard with controlled blocks, the evidence is good for diagnostic accuracy of cervical facet joint pain, with a prevalence of $36 \%$ to $60 \%$ with a false-positive rate of $27 \%$ to $63 \%$ with a single block. Based on 2 studies from the same group of authors, the evidence for $75 \%$ to $100 \%$ pain relief as the criterion standard with a single block is limited. The evidence is limited for a single diagnostic block with $50 \%$ to $74 \%$ pain relief as the criterion standard, whereas no studies were available assessing the accuracy of $50 \%$ to $74 \%$ pain relief as the criterion standard with controlled blocks.

Limitations: The limitations of this systematic review include a paucity of literature on outcomes, randomized, placebo-controlled trials and a lack of consensus on a gold standard.

Conclusions: Diagnostic cervical facet joint nerve blocks are safe, valid, and reliable. The strength of evidence for diagnostic facet joint nerve blocks is good with the utilization of controlled diagnostic blocks with at least $75 \%$ pain relief as the criterion standard; however, the evidence is limited for single blocks or dual blocks for relief of $50 \%$ to $74 \%$ and single blocks with at least $75 \%$ pain relief.

Key words: Chronic neck pain, cervical facet or zygapophysial joint pain, cervical medial branch blocks, controlled comparative local anesthetic blocks

Pain Physician 2012; 15:E807-E838 


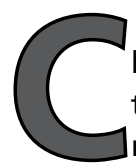

hronic persistent neck pain has been reported to be present in almost $50 \%$ of individuals who report neck pain at some point in their lives (13). Furthermore, neck pain is common in the general adult population with a prevalence of $48 \%$ in women and $38 \%$ in men, with persistent complaints $22 \%$ of women and $16 \%$ of men. Studies of the prevalence of chronic neck pain (1-20) and its impact on general health $(6,11,14)$ showed $14 \%$ of patients reporting Grade II to IV neck pain with high pain intensity with disability. Similar to low back pain, neck pain is also associated with significant economic, societal, and health impact, though not to the same extent as low back pain. In fact, neck pain is well recognized as a source of disability in the working population $(15,19,20)$.

Cervical intervertebral discs, cervical facet joints, atlanto-axial and atlanto-occipital joints, ligaments, fascia, muscles, and nerve root dura have been shown to be capable of transmitting pain in the cervical spine with resulting symptoms of neck pain, upper extremity pain, and headache. However, very little is known about the causes of neck pain since the epidemiologic studies do not describe either the source or cause of the pain $(2,17,21-23)$. Yin and Bogduk (23) in a study of 143 patients with chronic neck pain in a private practice pain clinic in the United States estimated the prevalence of discogenic pain in 16\%, zygapophysial joint pain $55 \%$, and lateral atlanto-axial joint pain 9\%. In summary, diagnosis remained elusive in $32 \%$ of those patients who completed investigations. Based on controlled diagnostic blocks, cervical facet joints have been implicated as being responsible for pain in the neck, head, and upper extremities in $36 \%$ to $60 \%$ in heterogenous population (24-34).

Cervical facet or zygapophysial joints have been shown to be a source of pain in the neck and referred pain in the head and upper extremities (35-39). Cervical facet joints are well innervated by the medial branches of the dorsal rami (40-46) with free and encapsulated nerve endings with nociceptors and mechanoreceptors $(41,42,46-62)$. Anatomical, biomechanical, and physiological basis has been described (63-70).

Dong et al (59) showed that neuronal stress activation is associated with painful facet injury, and that joint loading may directly mediate the behavior of the dorsal root ganglia (DRG) neurons in this class of injury. In vivo studies demonstrate that certain facet joint distractions initiate persistent firing of nociceptive afferents in the facet capsule (50), and induce persistent mechanical allodynia and spinal glial activation $(53,54,59,60)$. Quinn et al (58) showed that the frequency of neuronal firing increased in patients with neck pain compared to the non-painful and sham groups, as did the incidence and frequency of spontaneous and after discharge firing. They also showed that the proportion of cells in the deep laminae that responded as wide dynamic range neurons also increased in the painful group relative to non-painful or sham groups. They concluded that these findings suggest that excessive facet capsule stretch, while not producing visible tearing, can produce functional plasticity of dorsal horn neuronal activity. The increase in neuronal firing across a range of stimulus magnitude after injury provides the first direct evidence of neuronal modulation in the spinal cord following facet joint loading, and suggests that facet joint chronic pain following whiplash injury is driven, at least in part, by central sensitization.

Chua et al (57) also showed that there were differences in sensory processing between chronic cervical zygapophysial joint pain patients with and without cervicogenic headache. They showed that the main difference between patients with or without cervicogenic headache was the lateralization of pressure hyperalgesia to the painful side of the head of the headache patients, accompanied by cold as well as warm relative hyperesthesia on the painful side of the head and neck. They concluded that these results suggested that rostral neuraxial spread of central sensitization was probably linked to the trigeminal spinal nucleus. Dong et al (59) also showed spinal glutamatergic system potentiation of persistent behavioral hypersensitivity that is produced following dynamic whiplash-like joint loading. Even though there is continuing discussion on the role of facet joint degeneration in chronic neck pain as a rationale for the treatment of back pain, the morphology of lumbar facet joint degeneration has been described by means of microscopic inspection, histology, and clinical imaging techniques such as conventional tomography, computed tomography $(\mathrm{CT})$, magnetic resonance imaging (MRI), or plain radiography (61). In these studies, the pathological changes attributed to facet joint degeneration were articular cartilage thinning, sclerosis of the subchondral bone, osteophyte formation, or hypertrophy. Kettler et al (61) after evaluating the morphological changes of cervical facet joints in the elderly concluded that the prevalence of cervical facet joint degeneration is probably very high in individuals aged 50 years and more, with a tendency to increase in severity with age. All levels of the middle and lower cervical spines 
were affected to almost the same degree, whereas in the lumbar spine, an increase in degeneration towards the lower levels was reported. In most cases, the cartilage in the cervical spine was evenly degenerated all over the joint surface while in the lumbar spine, certain regions were reported to be affected predominantly. In this study, only specimens of facet joints from 59 to 92 aged persons were evaluated. In addition, degenerative and traumatic changes in the lower cervical spine facet joints have been reported (62). The evaluation was performed only in the lower cervical spine facet joints from C4 through C7. These findings supported the existing knowledge that males are more commonly affected by degenerative changes than females and that these changes commonly occur at a young age. Histomorphometry also confirmed the presence of synovial fluids in all of the facet joints. Furthermore, following spinal trauma, pathological lesions may be produced in the facet joints and/or accentuate already existing pathology. Hypertrophic change of facet joints in the cervical spine also have been described (71). In another study (72), it was illustrated that stretching the facet joint capsule beyond physiological range could result in an altered axonal morphology that may be related to secondary or delayed axotomy changes similar to those seen in central nervous system injuries where axons are subjected to stretching and shearing. It was concluded that these changes may contribute to neuropathic pain and are potentially related to neck pain after whiplash events. Morishita et al (71) examined the image and clinical characteristics of patients with cervical facet hypertrophy and the significance of such characteristics and concluded that hypertrophic change of facet joint occurred at the mid-level of the cervical spine, usually unilaterally, was more frequent in males, and was associated with neck pain. Whiplash may also cause increased laxity of the cervical capsular ligament (73). One interpretation is that capsular ligament injuries, in the form of increased laxity, may be one component perpetuating chronic pain and clinical instability in whiplash patients. In fact, Bogduk (74) in describing biological features of whiplash injury showed that a spectrum of injuries can occur in the zygapophysial joints in motor vehicle accidents based on results of postmortem studies. He concluded that the fact that multiple lines of evidence, using independent techniques, consistently implicate the cervical zygapophysial joints as a site of injury and source of pain, strongly suggesting that injury to these joints is a common basis for chronic neck pain after whiplash.
Curatolo et al (75) also discussed the role of tissue damage in whiplash-associated disorders. Their results demonstrated that numerous investigations conducted in animals, cadavers, healthy volunteers, and patients have documented lesions of various tissues. Furthermore, most lesions are undetected by imaging techniques. However, for zygapophysial (facet) joints, lesions have been predicted by bioengineering studies and validated through animal studies; for zygapophysial joint pain, a valid diagnostic test and a proven treatment are available. The influence of lower cervical joint pain on a range of motion also has been described (76). Hall et al (76) showed that the average range of unilateral rotation to the limited side during flexion-rotation test (FRT) was significantly reduced in the patients with lower cervical facet joint pain. Finally, Javanshir et al (77) investigated the differences in pressure and thermal pain hypersensitivity between patients with acute and chronic neck pain and healthy subjects. They found widespread decreased pressure pain thresholds in patients with chronic but not acute, mechanical neck pain as compared with controls. Furthermore, as compared with patients with acute neck pain and controls, patients with chronic neck pain also showed cold pain hypersensitivity. They concluded that the results supported the existence of different sensitization mechanisms between patients with acute and chronic mechanical insidious neck pain. However, neck muscle strength and its relationship to neck pain have not been widely studied.

Even though a preponderance of evidence supports the existence of cervical facet joint pain and its prevalence utilizing controlled diagnostic blocks, a significant proportion of patients suspected of cervical facet joint pain present with false-positive results of $27 \%$ to $63 \%(24-29,34,78)$. Thus, to maintain the accuracy of diagnosis, facet joint blocks must be performed under controlled conditions, either with a placebo or with controlled comparative local anesthetic blocks utilizing 2 local anesthetics of different durations of action. Falco et al (34) reported that the outcome measurement needs to be appropriate providing significant pain relief ( $\geq 80 \%$ ) and that the outcome must be the ability to perform previously painful movements with sustained pain relief. While diagnostic blocks may provide approximately 3 weeks of relief with the first block and approximately 6 weeks of relief with the second block $(79,80)$, Chua et al (81) showed that despite the return of neck pain after the local anesthetic agents wore off, patients admitted to generalized 
electrical hypoalgesia and significantly reduced conditioned pain modulation responses. They concluded that based on preliminary evidence, the perturbations to the sensory processing system from effective diagnostic blocks positively affect the tonic inhibitory system. They also stated, however, that conditioned pain modulation needs to be interpreted in the context of altered pain thresholds, and that any shift in the nociceptive balance between facilitatory and inhibitory control after therapeutic interventions has to be further investigated.

The latest systematic review (34), published in 2009, showed strong evidence for the diagnostic accuracy of cervical facet joint blocks. In addition, Rubinstein and van Tulder (82) in a best-evidence review of diagnostic procedures for neck and low back pain concluded that there was strong evidence for the diagnostic accuracy of facet joint blocks in the diagnosis of neck pain. Significant debate surrounds the various treatments utilized in the management of chronic neck pain arising from cervical facet joints $(2,34,82-96)$, even though the diagnosis has been well established.

The diagnosis of facet joints may not be made based on a radiologic evaluation or clinical assessment with certainty (97-99). There is little information on the validity or utility of a self-reported history in evaluating neck pain disorders (97-101). While clinical routine physical examination is more effective in ruling out cervical radiculopathy than confirming its presence, it's usefulness in non-radicular disorders or facet joint pain is debatable. Local tenderness is not diagnostic of zygapophysial joint pain in the cervical spine (102). A manual examination of the cervical spine is not a valid means of diagnosing cervical zygapophysial joint pain (100). There is however, some evidence that some features of inspection, range of motion, strength, palpation, and provocation tests can be useful. Range of motion has been described to be moderately reliable, as it does not seem to matter whether it is assessed by the clinician (assessing active or passive range of motion with or without a device) or self-described by the patient $(97,100-110)$. There is also some evidence that chronic whiplash-associated disorder patients and subjects with neck pain and myalgia have less mobility in the cervical spine compared with controls (111). Patients with chronic neck pain also may have slightly lower neck muscle strength compared with controls (107). Even then, a role for physiotherapists has been suggested in the screening of patients suitable for diagnostic cervical facet joint blocks (112). Schneider et al (112) showed that utilizing clinical prediction guides may allow practitioners to use the results of a patient's history, self-report measures, and physical examination toward optimal diagnostic and therapeutic decisions; namely, selecting the patient for cervical diagnostic facet joint blocks.

There is no evidence that common degenerative changes on a cervical MRI are strongly correlated with neck pain symptoms (97). The evidence illustrates that common degenerative changes are highly prevalent in asymptomatic subjects and are also prevalent with increasing age (113-130). Moreover, there is no evidence that common degenerative changes on cervical MRI are associated with pain in patients with suspected cervicogenic headache $(97,130)$. Multiple evaluations have been shown to be non-diagnostic to facet joint pain (124-129). The utilization of an MRI to evaluate patients with acute unilateral neck pain and restricted motion (125) showed no synovial effusion or inflammation around the joints of the cervical spine.

Single photon emission computerized tomography scan (SPECT) was shown to have increased uptake into the facet joints in only $43 \%$ of patients (131). While there is ample literature addressing low back pain, there is no significant literature for the cervical spine for the diagnosis of facet joint pain by SPECT (132-137).

Self assessment questionnaires; however, may have utility in routine clinical practice and research by categorizing patients' clinical presentation, subjective functional impact of neck pain and force over time (97). However, there is no evidence that a self-assessment questionnaire alone can accurately diagnose a structural cause of illness in patients with neck pain. There is evidence that generic questionnaires may be more useful than neck specific questionnaires for comparing individuals with neck pain with other disease groups $(105,108,109,138-141)$. In one study, however, it was shown that in patients with neck pain the use of a self-assessment questionnaire to monitor health care utilization showed poor recollection of health care utilization, rendering it unreliable as a source (100).

Thus, multiple evaluations may be the basis for a suspicion of, but not diagnosis of cervical facet joint pain. Even though debate continues on the diagnostic and therapeutic management of chronic pain in general and neck pain in particular, cervical facet joint interventions, along with multiple other interventions used in managing chronic neck pain, are increasing $(34,83-96,142-160)$.

The diagnostic and therapeutic literature was reviewed in 2009 (34). However, due to evolving concepts 
and increasing health care utilization, health care costs, resulting in a crisis in the United States, it is essential to update the evidence $(161,162)$. Thus, this systematic review was undertaken to evaluate and update the accuracy of diagnostic cervical facet joint interventions in the diagnosis of cervical facet joint pain (34).

\subsection{Methods}

The methodology utilized in this systematic review followed the review process derived from evidencebased systematic reviews and meta-analysis of diagnostic accuracy studies (34,82,163-184).

\subsection{Criteria for Considering Studies for This Review}

\subsubsection{Types of Studies}

Diagnostic accuracy of facet joint blocks evaluating cervical facet joint pain.

\subsubsection{Types of Participants}

Participants of interest were adults aged at least 18 years with chronic neck and upper extremity pain of at least 3 months duration.

Participants must have failed previous pharmacotherapy, exercise therapy, etc., prior to starting diagnostic interventional pain management techniques.

\subsubsection{Types of Interventions}

The interventions were diagnostic cervical facet joint blocks appropriately performed with proper technique under fluoroscopic or CT guidance.

\subsubsection{Types of Outcome Measures}

- The primary outcome parameter was pain relief concordant with the type of controlled diagnostic blocks performed.

- The secondary outcome measure was the ability to perform previously painful movements without significant pain or complications.

- At least 2 of the review authors independently, in an unblinded standardized manner, assessed the outcomes measures. Any disagreements between reviewers were resolved by a third author and consensus.

\subsection{Literature Search}

Searches were performed from the following sources without language restrictions:

1. PubMed from 1966 www.ncbi.nlm.nih.gov/sites/entrez?db=pubmed

2. EMBASE from 1980

www.embase.com/

3. Cochrane Library

www.thecochranelibrary.com/view/0/index.html

4. U.S. National Guideline Clearinghouse (NGC)

www.guideline.gov/

5. Previous systematic reviews and cross references

6. Clinical Trials

clinicaltrials.gov/

The search period was from 1966 through June 2012.

\subsection{Search Strategy}

The search strategy emphasized chronic neck pain of facet joint origin with a focus on all types of diagnostic interventions. Search terminology included cervical facet joint, cervical facet joint pain, cervical diagnostic facet joint blocks, cervical facet joint intraarticular injections, and medial branch blocks.

This systematic review focused only on diagnostic studies, including invasive techniques and reports of complications. Only cervical facet joint injections performed under fluoroscopy or CT imaging techniques were evaluated. Interventional techniques performed blindly or using other identification modalities were excluded. All studies describing appropriate outcome evaluations with proper statistical evaluations were reviewed. Reports without appropriate diagnosis, nonsystematic reviews, book chapters, and case reports were excluded.

At least 2 of the review authors independently, in an unblinded standardized manner, performed each search. All searches were combined to obtain a unified search strategy. Any disagreements between reviewers were resolved by a third author and consensus.

\subsection{Data Collection and Analysis}

The quality of each individual article used in this assessment was based on the Quality Appraisal of Reliability (QAREL) checklist (Table 1) (166). This checklist has been validated and utilized in multiple systematic reviews (167). Each study in the final sample of eligible manuscripts was assessed using a 12-item appraisal checklist designed to assess the quality and applicability of studies. The face validity of these checklists was established by consultation with methodology experts (166) and comparison with quality appraisal checklists used in other systematic reviews examining diagnostic 
reliability (185-190). This checklist was also developed in accordance to the Standards for Reporting Studies of Diagnostic Accuracy (STARD) (170), and the Quality Assessment of Diagnostic Accuracy Studies (QUADAS) $(170,171)$ appraisal tool. Studies were not given an overall numeric quality score; instead, each item was considered separately and graded as "yes," "no," "unclear," or "not applicable."

\subsubsection{Selection of Studies}

- In an unblinded standardized manner, 2 review authors screened the abstracts of all identified studies against the inclusion criteria.

- All articles with possible relevance were then retrieved in full text for comprehensive assessment of internal validity, quality, and adherence to inclusion criteria.

\subsubsection{Inclusion and Exclusion Criteria}

\section{Inclusion Criteria}

Prospective and retrospective studies published on the diagnosis of cervical facet joint pain in patients with chronic pain of greater than 3 months duration were included for review. Only the studies utilizing controlled diagnostic blocks under fluoroscopy were included. The criterion standard for diagnosis of cervical facet joint pain was at least $50 \%$ pain relief for the duration of local anesthetic and ability to perform previously painful movements.

\section{Exclusion Criteria}

All non-clinical studies were excluded. Ultrasound guided injections, case reports, book chapters, nonevidence-based guidelines, letters, and expert opinions were excluded.

\subsubsection{Clinical Relevance}

The clinical relevance of the included studies was evaluated according to 5 questions recommended by the Cochrane Back Review Group (Table 2) $(191,192)$. Each question was scored as positive (+) if the clinical relevance item was met, negative $(-)$ if the item was not met, and unclear (?) if data were not available to answer the question.

\subsubsection{Methodological Quality or Validity Assessment}

Each study was evaluated by at least 2 authors for stated criteria, with any disagreements discussed with a third reviewer. Authors with a perceived conflict of

Table 1. Quality Appraisal of Diagnostic Reliability (QAREL) checklist.

\begin{tabular}{|c|c|c|c|c|}
\hline Item & Yes & No & Unclear & N/A \\
\hline \multicolumn{5}{|c|}{$\begin{array}{l}\text { 1. Was the test evaluated in a spectrum of subjects representative of patients who would normally } \\
\text { receive the test in clinical practice? }\end{array}$} \\
\hline \multicolumn{5}{|c|}{$\begin{array}{l}\text { 2. Was the test performed by examiners representative of those who would normally perform the test in } \\
\text { practice? }\end{array}$} \\
\hline \multicolumn{5}{|l|}{ 3. Were raters blinded to the reference standard for the target disorder being evaluated? } \\
\hline \multicolumn{5}{|l|}{ 4. Were raters blinded to the findings of other raters during the study? } \\
\hline \multicolumn{5}{|l|}{ 5. Were raters blinded to their own prior outcomes of the test under evaluation? } \\
\hline \multicolumn{5}{|l|}{ 6. Were raters blinded to clinical information that may have influenced the test outcome? } \\
\hline \multicolumn{5}{|c|}{ 7. Were raters blinded to additional cues, not intended to form part of the diagnostic test procedure? } \\
\hline \multicolumn{5}{|l|}{ 8. Was the order in which raters examined subjects varied? } \\
\hline \multicolumn{5}{|l|}{ 9. Were appropriate statistical measures of agreement used? } \\
\hline \multicolumn{5}{|l|}{ 10. Was the application and interpretation of the test appropriate? } \\
\hline \multicolumn{5}{|c|}{$\begin{array}{l}\text { 11. Was the time interval between measurements suitable in relation to the stability of the variable being } \\
\text { measured? }\end{array}$} \\
\hline 12. If there were dropouts from the study, was this less than $20 \%$ of the sample. & & & & \\
\hline
\end{tabular}

Lucas N, Macaskill P, Irwig L, Moran R, Bogduk N. Reliability of physical examination for diagnosis of myofascial trigger points. Clin J Pain 2008; 25:80-89 (166). 
interest for any manuscript were recused from reviewing the manuscript.

Only diagnostic accuracy studies meeting at least $50 \%$ of applicable inclusion criteria were included for analysis. Studies scoring less than $50 \%$ are reported descriptively with critical analysis.

\subsubsection{Data Extraction and Management}

Two review authors independently, in an unblinded standardized manner, extracted the data from the included studies. Disagreements were resolved by discussion between the 2 reviewers; if no consensus could be reached, a third author was called in to break the impasse.

\subsubsection{Assessment of Heterogeneity}

Analysis of the evidence was based on diagnostic criteria as follows: 1 ) blocks in which the reference standard for diagnosis was between $50 \%$ to $74 \%$ pain relief with a single block; 2 ) blocks in which the reference standard for diagnosis was between $50 \%$ to $74 \%$ pain relief with either placebo controlled or comparative controlled diagnostic blocks; 3) blocks in which the reference standard for diagnosis was between $75 \%$ to $100 \%$ pain relief with a single block; and 4) blocks in which the reference standard for diagnosis was between $75 \%$ to $100 \%$ pain relief with either placebo controlled or comparative controlled diagnostic blocks, to reduce clinical heterogeneity.

\subsubsection{Measurement of Treatment Effect in Data Synthesis (Meta-Analysis)}

Data was separately summarized using meta-analysis when at least 5 studies per type of diagnostic criteria were available that met the inclusion criteria (e.g., single block, double blocks, and $50 \%$ to $80 \%$ relief).
The minimum acceptable relief was considered to be $50 \%$; however, data were analyzed for $\geq 75 \%$ and $50 \%$ to $74 \%$ relief as the cutoff threshold for a positive block during the performance of previously painful movements. Four separate diagnostic categories were evaluated (i.e., $50 \%$ to $74 \%$ relief as the cutoff threshold with single and dual blocks; and $75 \%$ to $100 \%$ relief as the cutoff threshold with single or dual blocks). For dual blocks, there had to have been a concordant response with short-acting and long-acting local anesthetics, or placebo.

\subsubsection{Integration of Heterogeneity}

A meta-analysis was performed only if there were at least 5 homogeneous studies meeting the inclusion criteria for each variable.

Statistical heterogeneity was explored using univariate meta-regression (193).

\subsection{Summary Measures}

Summary measures included $50 \%$ to $74 \%$ or $75 \%$ to $100 \%$ pain relief with the capability of performing previously painful movements concordant with the duration of local anesthetic.

\subsection{Analysis of Evidence}

The analysis of the evidence was performed based on United States Preventive Services Task Force (USPSTF) criteria (194) as illustrated in Table 3, which has been utilized by multiple authors $(164,165,179,194-203)$.

The analysis was conducted using 3 levels of evidence ranging from good, fair, and limited or poor $(164,165,179,194-203)$.

At least 2 of the review authors independently, in an unblinded standardized manner, analyzed the evi-

Table 2. Clinical relevance questions.

\begin{tabular}{|c|c|c|c|}
\hline & $\mathbf{P}(+)$ & $\mathbf{N}(-)$ & $\begin{array}{c}\mathrm{U} \\
\text { (unclear) }\end{array}$ \\
\hline $\begin{array}{l}\text { A) Are the patients described in detail so that one can decide whet } \\
\text { are treated practice? }\end{array}$ & & & \\
\hline $\begin{array}{l}\text { B) Are the interventions and treatment settings described in suffic } \\
\text { practice? }\end{array}$ & & & \\
\hline C) Were clinically relevant outcomes measured and reported? & & & \\
\hline D) Is the size of the effect clinically meaningful? & & & \\
\hline E) Do the likely treatment benefits outweigh the potential harms? & & & \\
\hline
\end{tabular}

Scoring adapted and modified from Staal JB, et al. Injection therapy for subacute and chronic low-back pain. Cochrane Database Syst Rev 2008; 3:CD001824 (192). 
Table 3. Method for grading the overall strength of the evidence for an intervention.

\begin{tabular}{|l|l|}
\hline Grade & Definition \\
\hline Good & $\begin{array}{l}\text { Evidence includes consistent results from well-designed, well-conducted studies in representative populations that directly } \\
\text { assess effects on health outcomes (at least } 2 \text { consistent, higher-quality RCTs or studies of diagnostic test accuracy). }\end{array}$ \\
\hline Fair & $\begin{array}{l}\text { Evidence is sufficient to determine effects on health outcomes, but the strength of the evidence is limited by the number, } \\
\text { quality, size, or consistency of included studies; generalizability to routine practice; or indirect nature of the evidence on } \\
\text { health outcomes (at least one higher-quality trial or study of diagnostic test accuracy of sufficient sample size; } 2 \text { or more } \\
\text { higher-quality trials or studies of diagnostic test accuracy with some inconsistency; at least } 2 \text { consistent, lower-quality trials } \\
\text { or studies of diagnostic test accuracy, or multiple consistent observational studies with no significant methodological flaws). }\end{array}$ \\
\hline Limited or Poor & $\begin{array}{l}\text { Evidence is insufficient to assess effects on health outcomes because of limited number or power of studies, large and } \\
\text { unexplained inconsistency between higher-quality trials, important flaws in trial design or conduct, gaps in the chain of } \\
\text { evidence, or lack of information on important health outcomes. }\end{array}$ \\
\hline
\end{tabular}

Adapted and modified from methods developed by U.S. Preventive Services Task Force (179,194-203).

dence. Any disagreements between reviewers were resolved by a third author and consensus. If there were any conflicts of interest (e.g., authorship), those reviewers were recused from assessment and analysis.

\subsection{Outcome of the Studies}

Outcomes included the prevalence of cervical facet joint pain and false-positive rate. Based on the above parameters, the reliability of the data derived from each study was assessed.

\subsection{Results}

Figure 1 shows the flow diagram of study selection. There were 26 considered for inclusion (23-33,35$39,43,78,159,204-210)$. Among these, 5 studies evaluated pain patterns (35-39), and were therefore not included in the accuracy or prevalence evaluation. Diagnostic accuracy or false-positive rate was evaluated in 12 studies $(23-25,27,29,30,32,33,78,159,204,206)$. An additional 8 studies evaluated the influence of various factors on the diagnosis and prevalence of facet joint pain $(26,28,31,205,206,208-210)$. There was one study that failed to meet the inclusion criteria, in which Barnsley and Bogduk (43) assessed the specificity of medial branch blocks without an evaluation of the accuracy of false-positive rates.

\subsection{Diagnostic Accuracy Studies}

Table 4 illustrates characteristics of the diagnostic accuracy studies considered for inclusion (23$25,27,29,30,32,33,78,159,204,206)$. Of these, one study (206) utilized $50 \%$ to $74 \%$ relief as the criterion standard or cutoff threshold for a positive block, whereas 2 studies utilized $75 \%$ to $100 \%$ pain relief as the criterion standard with a single block $(159,204)$. There were no studies evaluating with controlled diagnostic blocks with $50 \%$ relief as the criterion standard. There were 9 studies utilizing controlled diagnostic blocks with a > $75 \%$ cutoff threshold $(23-25,27,29,30,32,33,78)$.

\subsection{Factors Influencing Diagnosis}

Table 5 illustrates the study characteristics of published reports of cervical facet joint blocks evaluating the influence of various factors on diagnostic accuracy $(26,28,31,205,206,208-210)$.

\subsection{Clinical Relevance}

Of the 19 studies assessed for clinical relevance $(23-33,78,159,204-206,208-210), 18$ of the studies met criteria with score of 3 of 5 or greater (23$33,78,159,204,206,208-210)$. Table 6 illustrates assessment of clinical relevance.

\subsection{Methodological Quality Assessment}

A methodological quality assessment of diagnostic accuracy studies meeting inclusion criteria was carried out utilizing QAREL criteria as shown in Table 7. Studies achieving $50 \%$ or higher scores were included. Scores of $67 \%$ or higher were considered to be high quality, $50 \%$ were considered to be moderate quality, and studies scoring less than $50 \%$ were considered to be of poor quality and excluded.

\subsection{Meta-Analysis of Diagnostic Accuracy Studies}

There were 3 randomized trials $(33,78,206)$ and 2 placebo-controlled studies of diagnostic accuracy $(33,78)$. There was one study in the single block group using $50 \%$ to $74 \%$ relief as the cutoff threshold (206). Two studies met inclusion that utilized a single block 


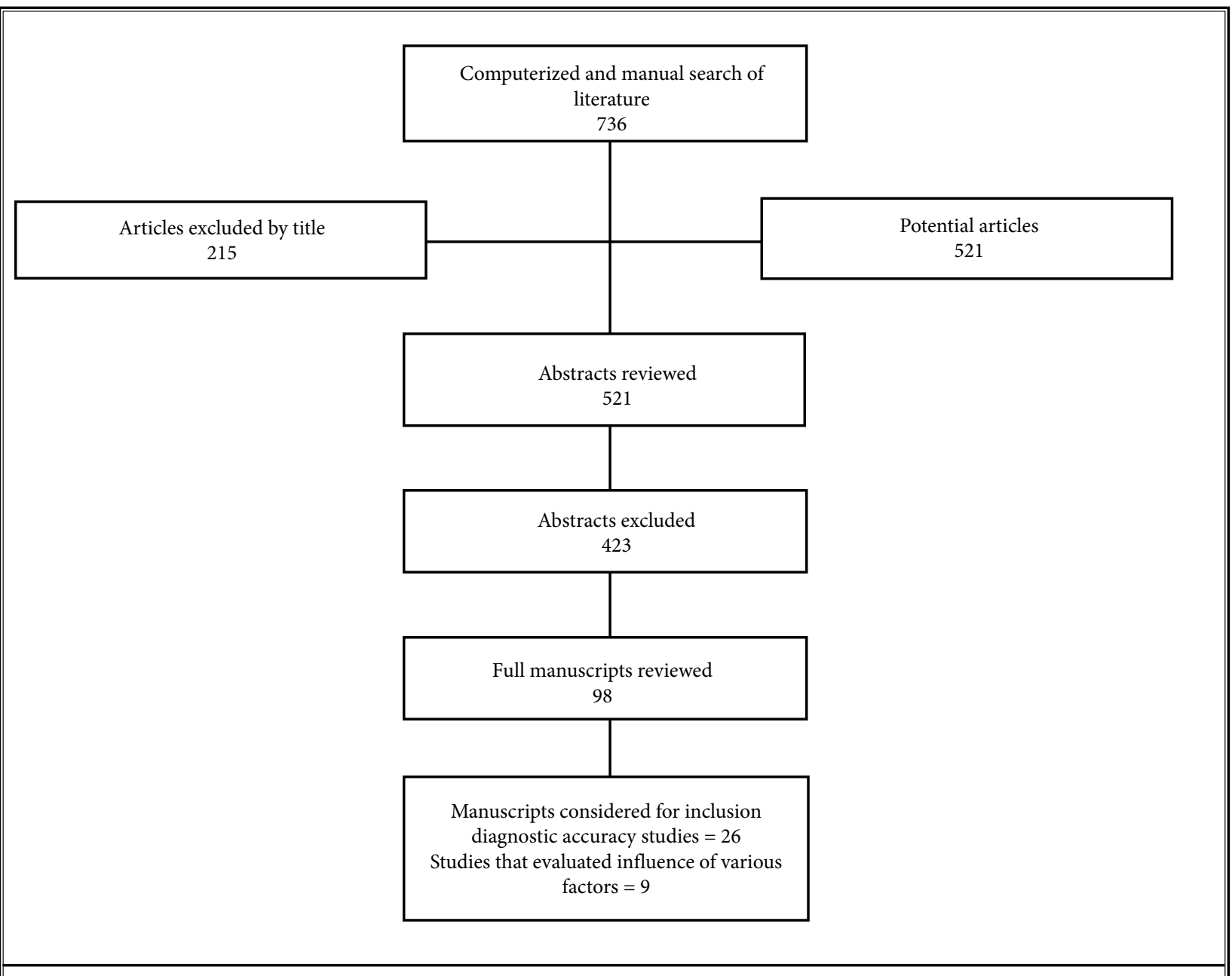

Fig. 1. The flow diagram illustrating published literature evaluating diagnostic cervical facet jointinjections.

with a cutoff threshold $>75 \%$ pain relief $(159,204)$. There were no studies with a cutoff between $50 \%$ and $74 \%$ pain relief that employed controlled diagnostic blocks as the criterion standard.

There were 9 studies $(23-25,27,29,30,32,33,78)$ using controlled diagnostic blocks with a criterion standard ranging between $75 \%$ and $100 \%$ relief. In this evaluation, 4 studies utilized $\geq 90 \%$ pain relief $(30,32,33,78)$, whereas 5 studies utilized $75 \%$ or greater relief as criterion standard $(23-25,27,29)$. Inclusion criteria were different. Thus, there was homogeneity only among the 4 studies $(24,25,27,29)$. Consequently, there was no meta-analysis performed.

\subsection{Analysis of Evidence}

The evidence was synthesized based on the relief criteria when cervical facet joint injections were performed. Table 8 illustrates the results of diagnostic studies.

\subsubsection{Single Block with $50 \%$ to $74 \%$ Pain Relief}

There was only one study evaluating the role of cervical facet joint nerve blocks with $\geq 50 \%$ relief with a single block as the criterion standard (206). This was not designed to be a prevalence study; however, it showed a prevalence of $25 \%$ in patients with $0.5 \mathrm{~mL}$ of bupivacaine administered and $55 \%$ in patients administered with $0.25 \mathrm{~mL}$ of bupivacaine. 


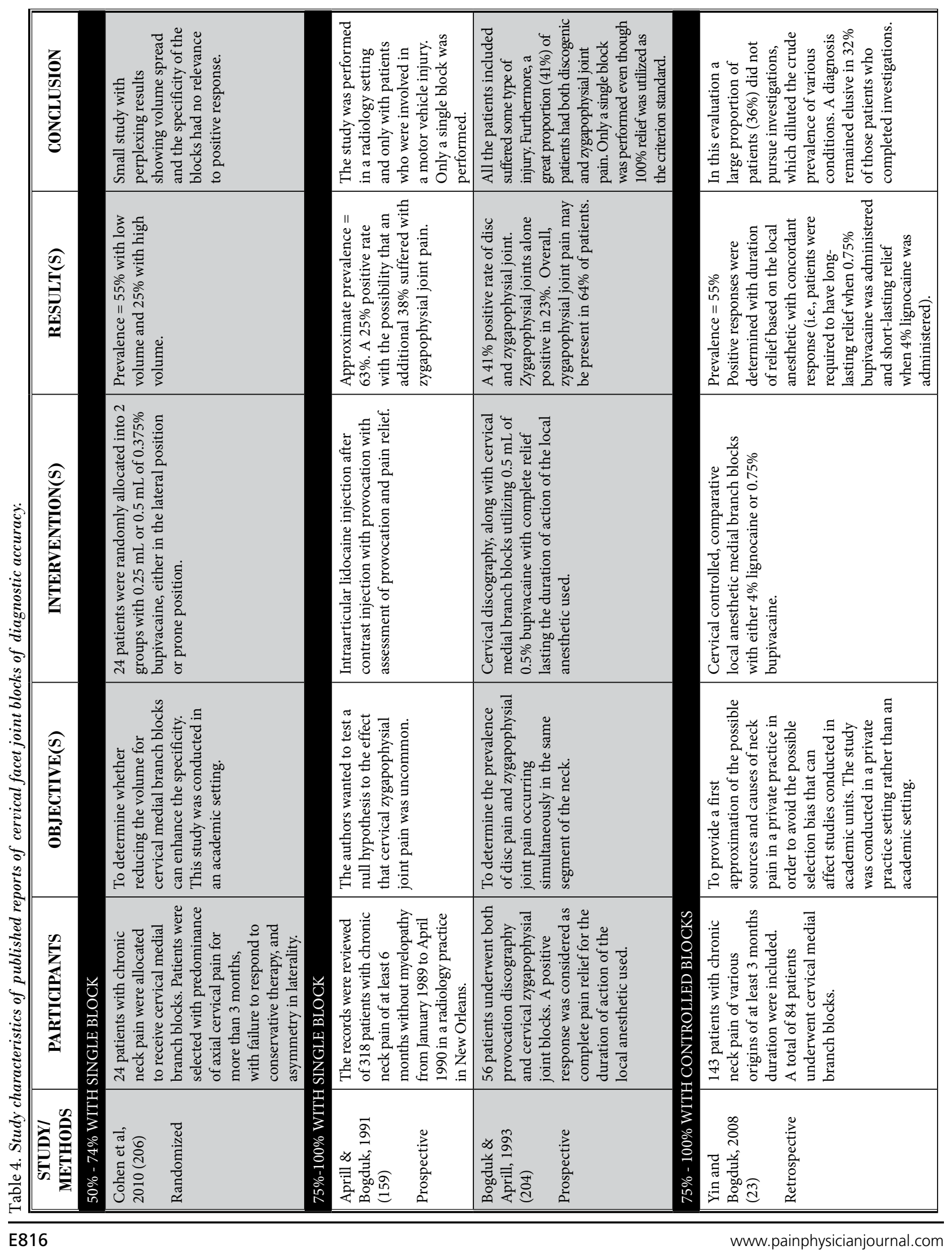




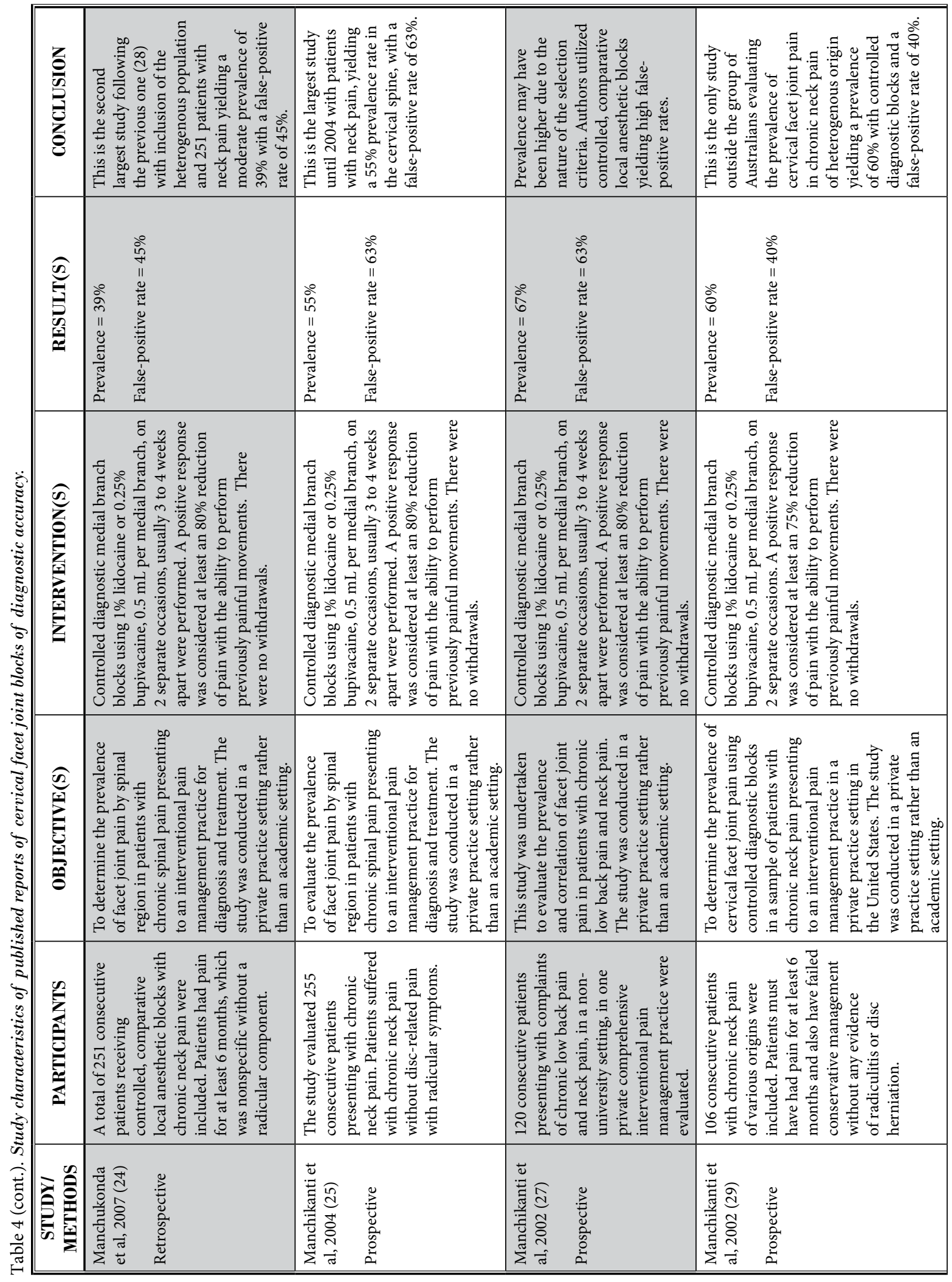

www.painphysicianjournal.com 


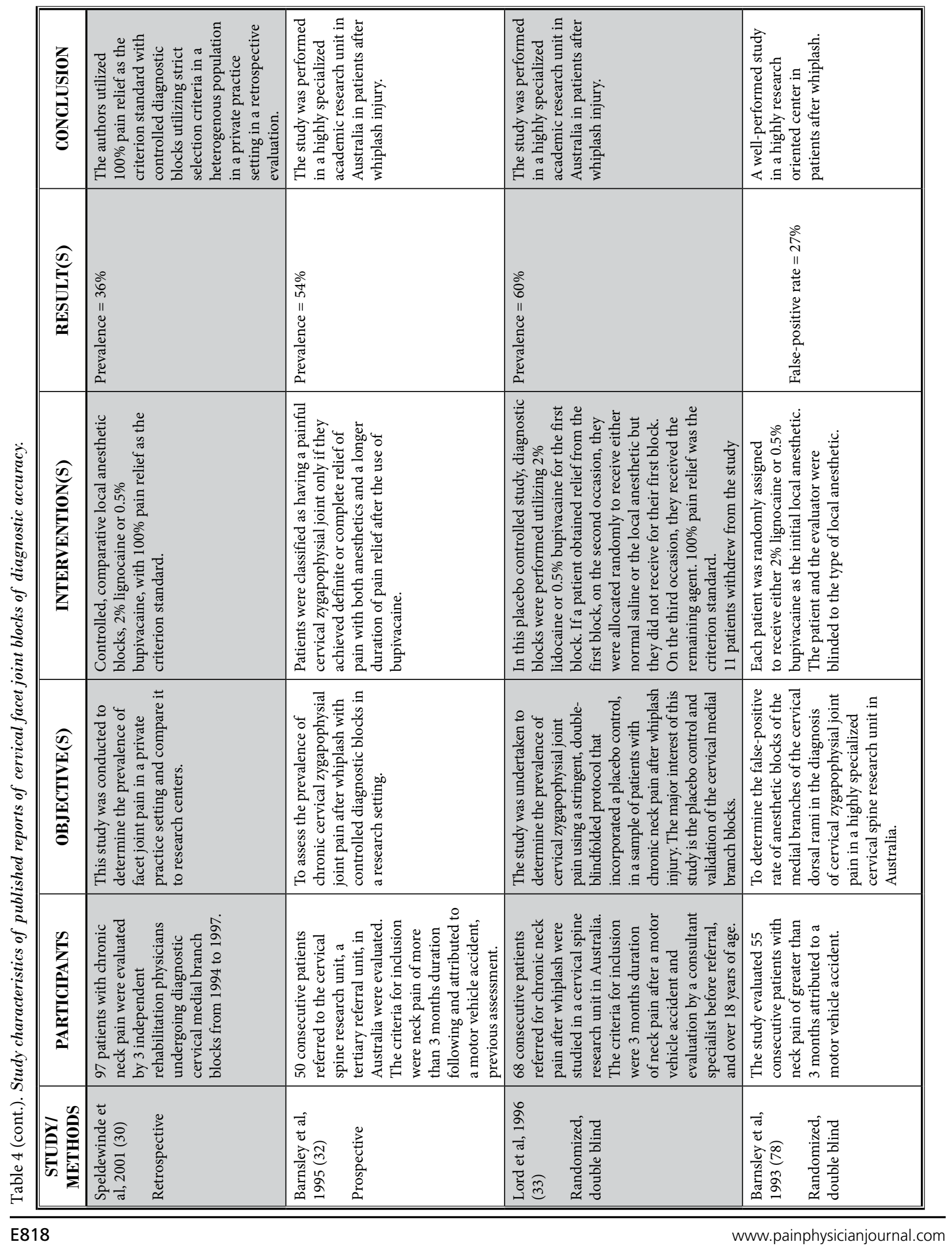




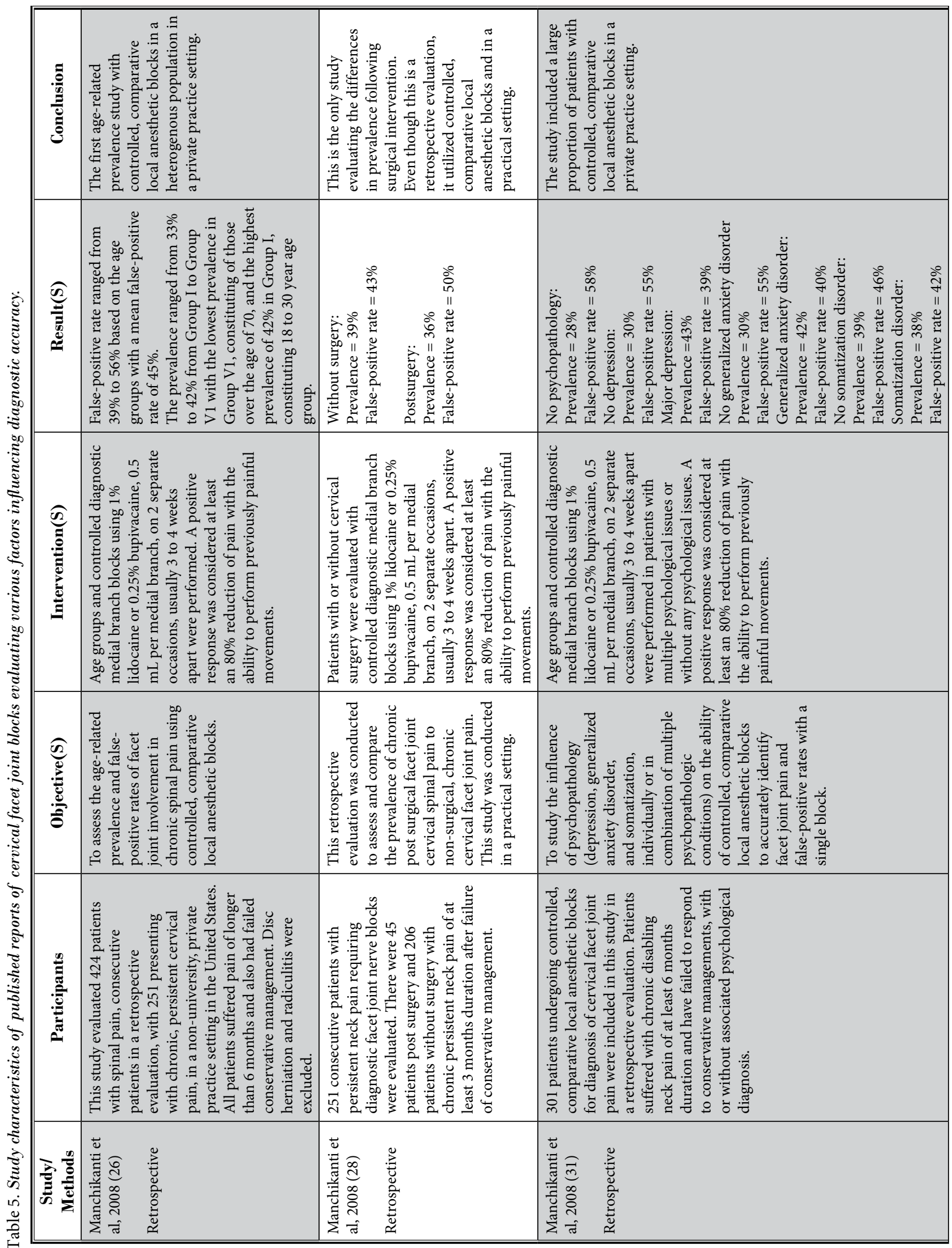




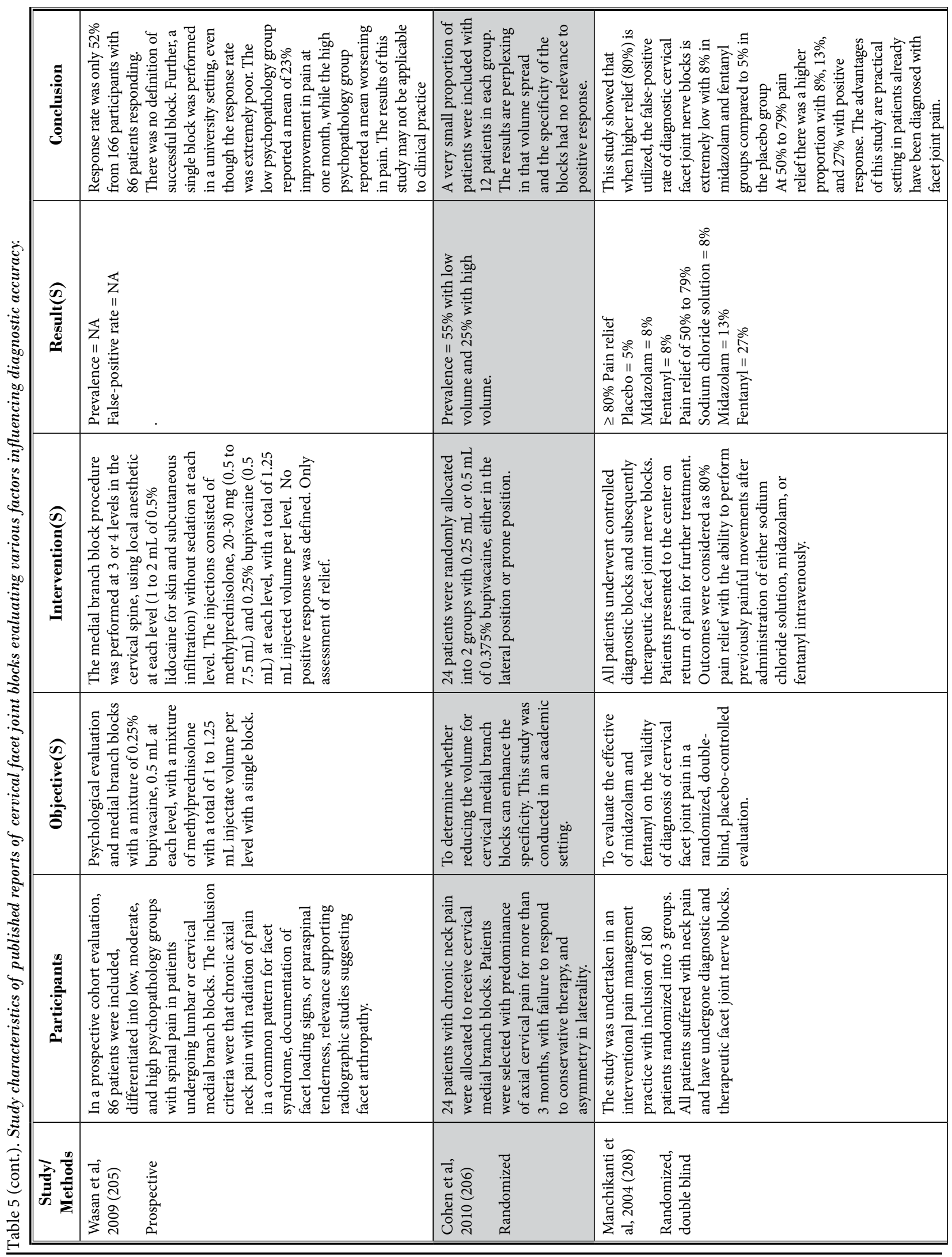




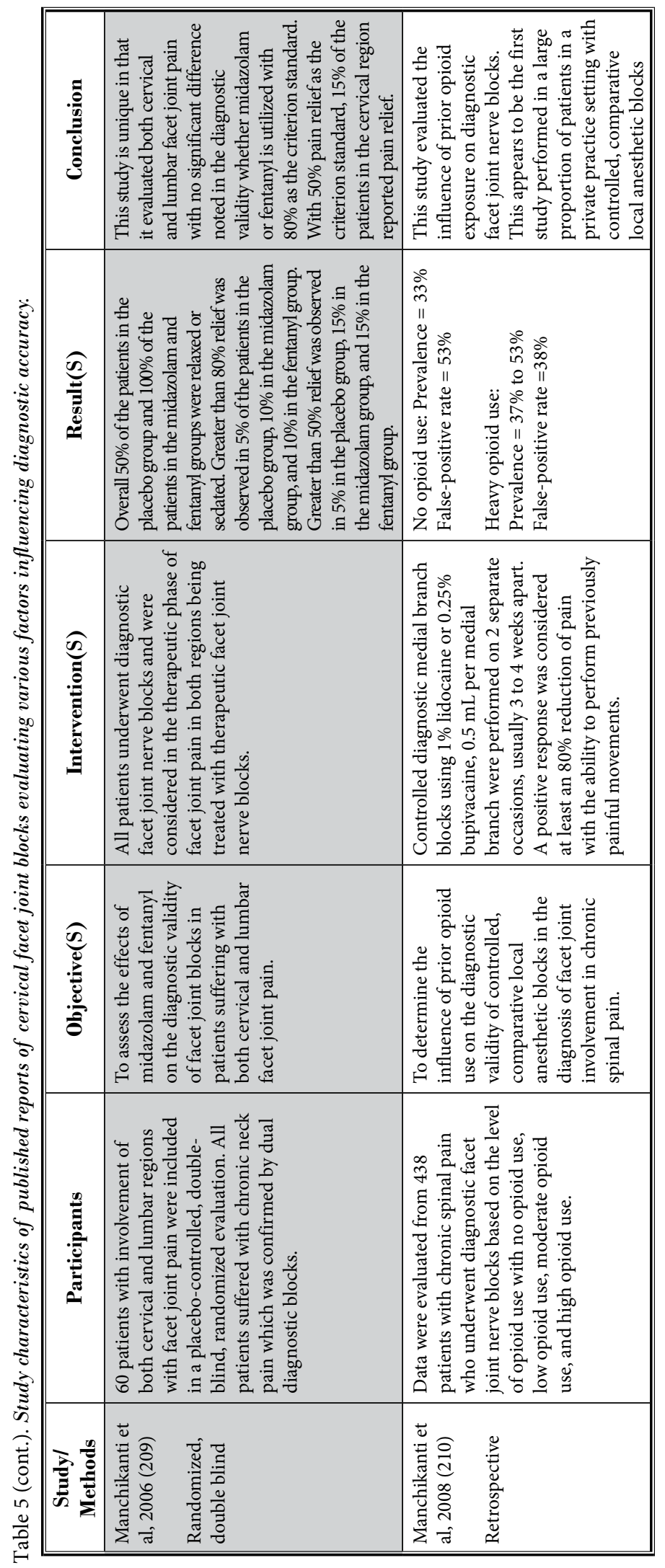

2.6.2 Single Block with $75 \%$ to $100 \%$ Relief

There were 2 studies meeting the inclusion criteria evaluating cervical facet joint pain using a cutoff threshold between $75 \%$ and $100 \%$ relief following a single block, by the same authors $(159,204)$. They evaluated neck pain in combination with discography and diagnostic cervical medial branch blocks in patients sustaining chronic neck pain after a motor vehicle injury. The prevalence in this group was $64 \%$ in one study (204) and definitively $23 \%$ and probably $64 \%$ in the other study.

\subsubsection{Controlled Blocks with $75 \%$ to $100 \%$ Relief}

There were a total of 9 studies meeting the inclusion criteria $(23-25,27,29,30,32,33,78)$. One study evaluated only false-positive rates (78).

Using between $75 \%$ and $100 \%$ pain relief as the criterion standard with controlled diagnostic blocks has been advocated by some as the most rigorous means for diagnosing cervical facet joint pain.

Among the 8 studies assessing the prevalence $(23-25,27,29,30,32,33)$, all of them utilized $80 \%$ or more relief as the criterion standard except for one study (29) that utilized $\geq$ $75 \%$ as the criterion standard. The prevalence of facet joint pain in these studies varied from $39 \%$ to $60 \%$ in heterogenous population.

\subsection{Factors Affecting Diagnosis}

Eight studies were available to evaluate the multiple factors affecting the diagnosis of cervical facet joint pain $(26,28,31,205,206,208$ 210). Among these, one study evaluated the age-related prevalence of cervical facet joint pain (26), 2 studies evaluated the influence of psychological factors $(31,205)$, one study evaluated the diagnostic volume (206), 2 studies evaluated the role of sedation $(208,209)$, and one study evaluated the role of opioid usage on the validity of the diagnostic facet joint nerve blocks (210).

\subsection{Level of Evidence}

Based on the USPSTF criteria, the evidence was classified as either good, fair, and limited or poor. 
Table 6. Clinical relevance of included studies.

\begin{tabular}{|c|c|c|c|c|c|c|}
\hline Manuscript Author(s) & $\begin{array}{l}\text { A) Patient } \\
\text { description }\end{array}$ & $\begin{array}{l}\text { B) Description of } \\
\text { interventions and } \\
\text { treatment settings }\end{array}$ & $\begin{array}{l}\text { C) Clinically } \\
\text { relevant } \\
\text { outcomes }\end{array}$ & $\begin{array}{l}\text { D) Clinical } \\
\text { importance }\end{array}$ & $\begin{array}{l}\text { E) Benefits } \\
\text { versus } \\
\text { potential } \\
\text { harms }\end{array}$ & $\begin{array}{c}\text { Total } \\
\text { Criteria } \\
\text { Met }\end{array}$ \\
\hline Yin \& Bogduk (23) & + & + & + & + & + & $5 / 5$ \\
\hline Manchukonda et al (24) & + & + & + & + & + & $5 / 5$ \\
\hline Manchikanti et al (25) & + & + & + & + & + & $5 / 5$ \\
\hline Manchikanti et al (26) & + & + & + & + & + & $5 / 5$ \\
\hline Manchikanti et al (27) & + & + & + & + & + & $5 / 5$ \\
\hline Manchikanti et al (28) & + & + & + & + & + & $5 / 5$ \\
\hline Manchikanti et al (29) & + & + & + & + & + & $5 / 5$ \\
\hline Speldewinde et al (30) & + & + & + & + & + & $5 / 5$ \\
\hline Manchikanti et al (31) & + & + & + & + & + & $5 / 5$ \\
\hline Barnsley et al (32) & + & + & + & + & + & $5 / 5$ \\
\hline Lord et al (33) & + & + & + & + & + & $5 / 5$ \\
\hline Barnsley et al (78) & + & + & + & + & + & $5 / 5$ \\
\hline Aprill \& Bogduk (159) & + & + & + & + & + & $5 / 5$ \\
\hline Bogduk \& Aprill (204) & + & + & + & + & + & $5 / 5$ \\
\hline Wasan et al (205) & + & + & - & - & - & $2 / 5$ \\
\hline Cohen et al (206) & + & + & - & - & + & $3 / 5$ \\
\hline Manchikanti et al (208) & + & + & + & + & + & $5 / 5$ \\
\hline Manchikanti et al (209) & + & + & + & + & + & $5 / 5$ \\
\hline Manchikanti et al (210) & + & + & + & + & + & $5 / 5$ \\
\hline
\end{tabular}

+ = positive; - = negative; $\mathrm{U}=$ unclear

Scoring adapted from Staal JB, et al. Injection therapy for subacute and chronic low-back pain. Cochrane Database Syst Rev 2008; 3:CD001824 (192).

\subsubsection{Single block with $50 \%$ to $74 \%$ Relief}

The evidence is limited based on one study with a single block with $50 \%$ to $74 \%$ pain relief as the criterion standard (206).

\subsubsection{Single Block with $75 \%$ to $100 \%$ Relief}

The evidence for a single block with $75 \%$ to $100 \%$ relief as the criterion standard is limited based on the results of two studies from the same group of authors $(159,204)$.

\subsubsection{Dual Blocks with $50 \%$ to $74 \%$ Relief}

No studies were available in this category.

\subsubsection{Controlled Blocks with $75 \%$ to $100 \%$ Relief}

The evidence for controlled diagnostic blocks with $75 \%$ to $100 \%$ relief as the criterion standard is good based on 9 high-quality studies $(23-25,27,29,30,32,33,78)$ in a heterogeneous group of neck pain patients.

\subsubsection{Summary of Evidence}

Overall, when $75 \%$ or greater relief is utilized as the criterion standard with controlled blocks, the evidence is good based on multiple high quality studies of diagnostic accuracy incorporating prevalence with or without false positive rates. The evidence is limited or not available with all other categories.

\subsection{Complications}

Complications from intraarticular injections, medial branch blocks, or radiofrequency thermoneurolysis in the cervical spine are exceedingly rare $(2,34,43,83$ $85,88,89,92-96,157-160,211-244)$. However, serious complications with cervical facet joint injections may 
Diagnostic Utility of Cervical Facet Joint Injections: Update

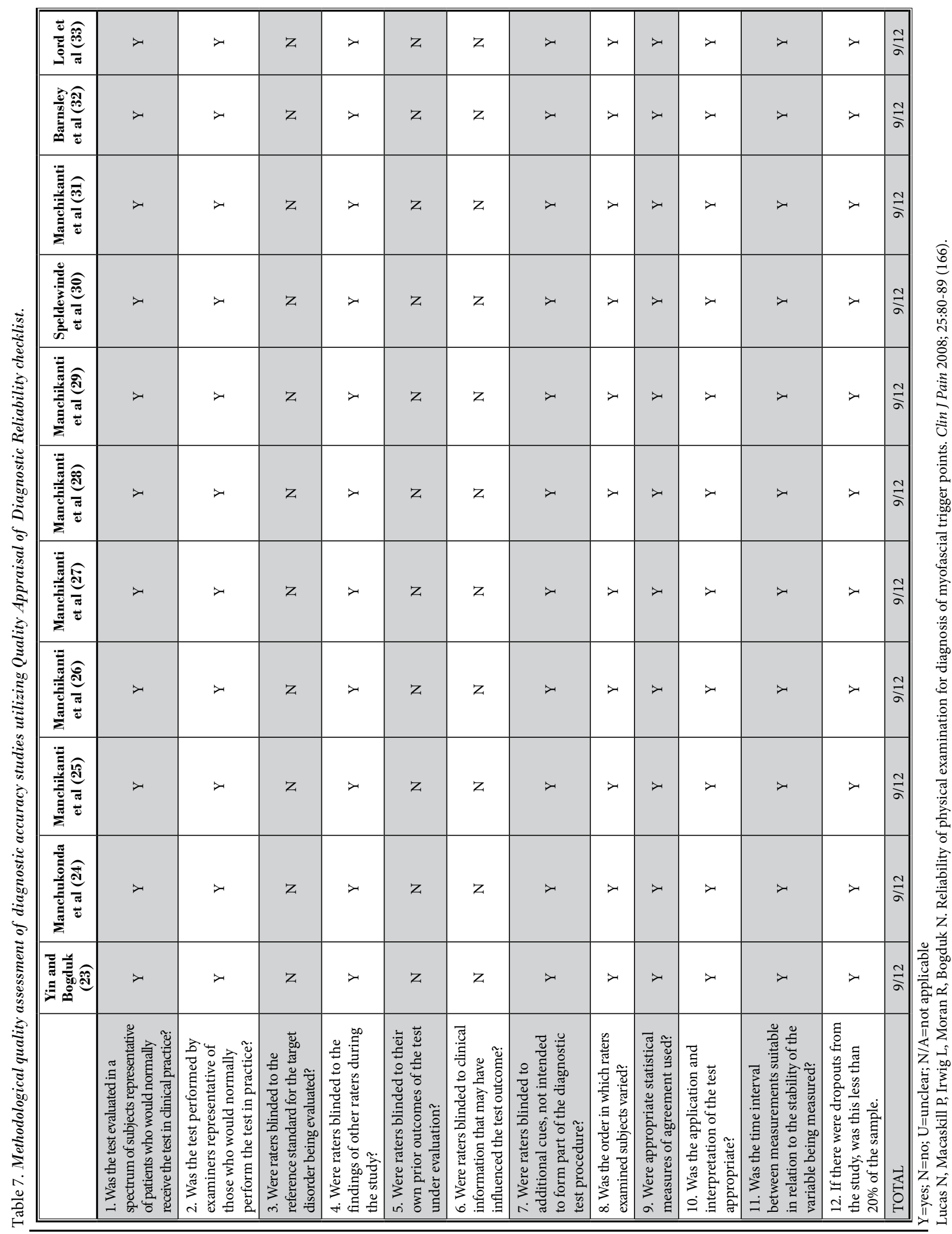




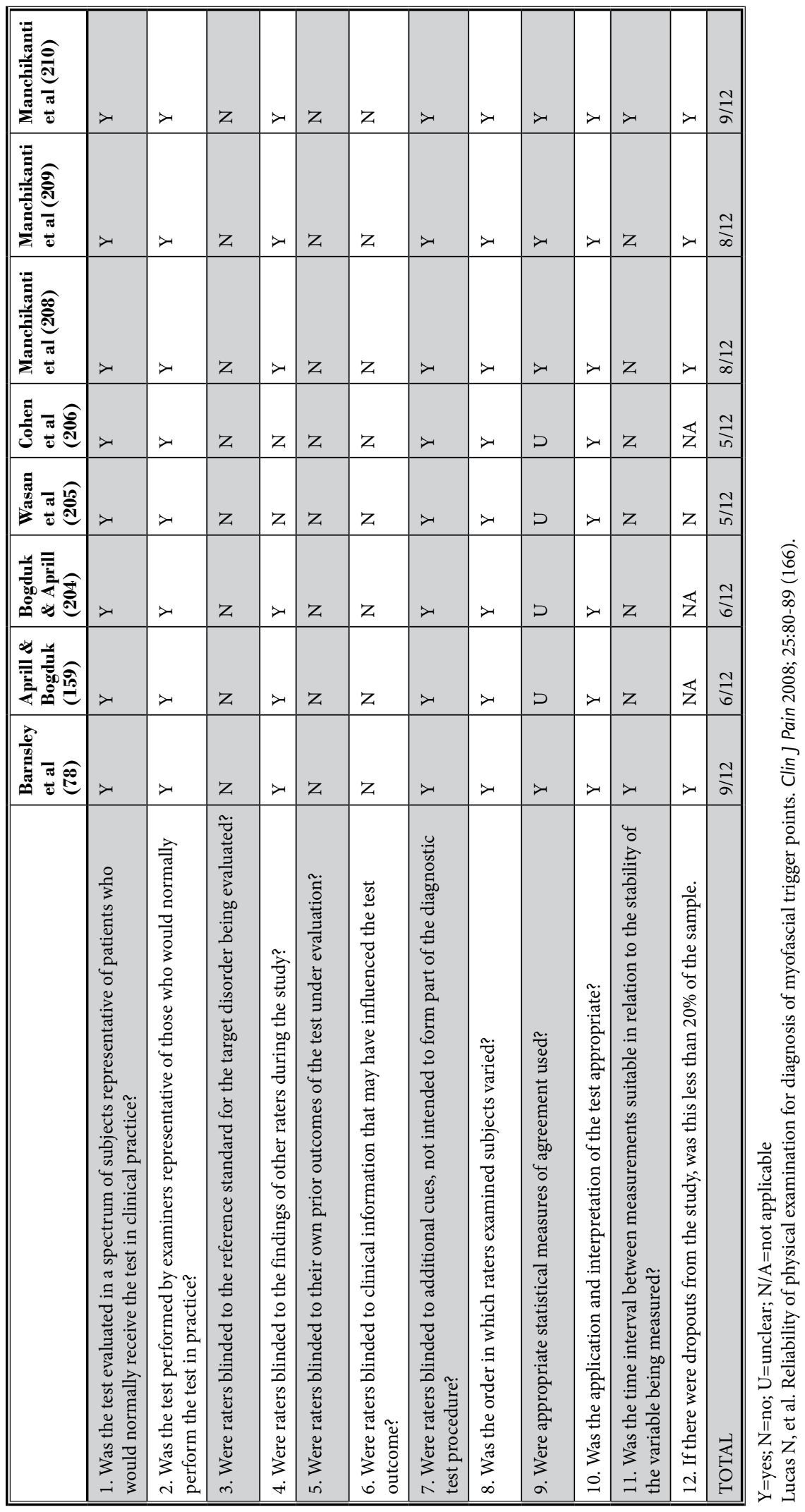


Diagnostic Utility of Cervical Facet Joint Injections: Update

Table 8. Data of prevalence and false-positive rates of pain of cervical facet joint origin based on diagnostic blocks.

\begin{tabular}{|c|c|c|c|c|c|}
\hline Study & \% Relief Used & $\begin{array}{l}\text { Methodological } \\
\text { Criteria Score }\end{array}$ & $\begin{array}{l}\text { Number of } \\
\text { Subjects }\end{array}$ & $\begin{array}{c}\text { Prevalence Estimates } \\
\text { with } 95 \% \text { Confidence } \\
\text { Intervals } \\
\end{array}$ & $\begin{array}{c}\text { False-Positive Rate } \\
\text { with } 95 \% \text { Confidence } \\
\text { Intervals } \\
\end{array}$ \\
\hline \multicolumn{6}{|c|}{$50 \%-74 \%$ with Single Block } \\
\hline Cohen et al (206) & $>50 \%$ & $5 / 12$ & 24 & $\begin{array}{l}55 \% \text { with low volume and } \\
25 \% \text { with high volume }\end{array}$ & NA \\
\hline \multicolumn{6}{|c|}{$75 \%-100 \%$ with Single Block } \\
\hline Aprill \& Bogduk (159) & $\geq 90 \%$ & $6 / 12$ & 318 & $25 \%-63 \%$ & NA \\
\hline Bogduk \& Aprill (204) & $\geq 90 \%$ & $6 / 12$ & 56 & $41 \%-64 \%$ & NA \\
\hline \multicolumn{6}{|c|}{$75 \%-100 \%$ with Controlled Blocks } \\
\hline Yin and Bogduk (23) & $>80 \%$ & $9 / 12$ & 143 & $55 \% *(95 \% \mathrm{CI}, 38 \%, 62 \%)$ & NA \\
\hline Manchukonda et al (24) & $>80 \%$ & $9 / 12$ & 251 of 500 & $39 \%(95 \%$ CI, 32\%, 45\%) & $45 \%(95 \%$ CI $37 \%, 52 \%)$ \\
\hline Manchikanti et al (25) & $>80 \%$ & $9 / 12$ & 255 of 500 & $55 \%(95 \%$ CI, $49 \%, 61 \%)$ & $63 \%(95 \%$ CI 54\%, 72\%) \\
\hline Manchikanti et al (27) & $>80 \%$ & $9 / 12$ & 120 & $67 \%(95 \%$ CI $58 \%, 75 \%)$ & $63 \%(95 \%$ CI $48 \%, 78 \%)$ \\
\hline Manchikanti et al (29) & $>75 \%$ & $9 / 12$ & 106 & $60 \% \%(95 \%$ CI, $50 \%, 70 \%)$ & $40 \% \%(95 \%$ CI, $34 \%, 46 \%)$ \\
\hline Speldewinde et al (30) & $>90 \%$ & $9 / 12$ & 97 & $36 \%(95 \%$ CI, $27 \%, 45 \%)$ & NA \\
\hline Barnsley et al (32) & $>90 \%$ & $9 / 12$ & 50 & $54 \%(95 \%$ CI, 40\%, 68\%) & NA \\
\hline Lord et al (33) & $>90 \%$ & $9 / 12$ & 68 & $60 \%(95 \%$ CI, 46\%, 73\%) & NA \\
\hline Barnsley et al (78) & $>90 \%$ & $9 / 12$ & 55 & NA & $27 \%(95 \%$ CI, $15 \%, 38 \%)$ \\
\hline
\end{tabular}

$\mathrm{NA}=$ not available or not applicable; $\mathrm{CI}=$ confidence interval; ${ }^{*}=$ adjusted

occur. Complications include those related to placement of the needle, and those related to the administration of various drugs.

The proximity of the needle to the vertebral artery, spinal cord, and nerve root creates risk for injury and makes precise and accurate needle placement exceedingly important. Complications may include dural puncture, spinal cord trauma, subdural injection, neural trauma, injection into the intervertebral foramen and intravertebral arteries; intravascular injection into veins or vertebral arteries; infectious complications including epidural abscess and bacterial meningitis; and side effects related to the administration of steroids, local anesthetics, and other drugs.

Okada (231) showed that in a series of cervical facet joint injections, a communicating pathway existed in $80 \%$ of subjects between the facet joint and interlaminar space, the opposite facet joint, extradural space, and interspinous space when volumes in excess of $1 \mathrm{~mL}$ were used.

Vertebral artery and ventral ramus damage, along with a risk of embolus resulting in serious neurological sequelae with spinal cord damage and cerebral infarction are exceedingly rare, but are potential complica- tions with cervical facet joint injections.

Other minor complications include lightheadedness, flushing, sweating, nausea, hypotension, syncope, pain at the injection site, and headaches. Side effects related to the administration of steroids are generally attributed to the chemistry or to the pharmacology of the steroids (229). These include suppression of pituitary-adrenal axis, hyperadrenocorticism, Cushing's syndrome, osteoporosis, avascular necrosis of the bone, steroid myopathy, epidural lipomatosis, weight gain, fluid retention, and hyperglycemia.

A study by Manchikanti et al (240) included over 7,500 episodes or 43,000 facet joint nerve blocks performed under fluoroscopic guidance in an ambulatory surgery center by one of 3 physicians. Multiple side effects and complications observed with cervical facet joint nerve blocks included intravascular penetration of $20 \%$, local bleeding in $67 \%$, oozing in $29 \%$, with local hematoma seen only in $2.3 \%$ of the patients with profuse bleeding, bruising, soreness, nerve root irritation, and all other effects such as vasovagal reactions observed in $1 \%$ or less of the episodes.

A spinal cord trauma or injection can lead to quadriplegia, motor weakness, loss of proprioception 
and sensory function, bowel and bladder dysfunction, Brown-Sequard syndrome, and spinal cord infarction.

\subsection{Discussion}

This systematic review provides current evidence for the diagnostic accuracy of cervical facet or zygapophysial joint nerve blocks in managing chronic pain of facet joint origin. Based on the results of this evaluation, the evidence for diagnostic facet joint blocks utilizing at least $75 \%$ pain relief as the criterion standard with controlled diagnostic blocks is good based on USPSTF criteria. Utilizing 8 high quality studies that met the inclusion criteria, the prevalence of chronic cervical facet joint pain related to neck pain is very common, ranging from $36 \%$ to $60 \%$ in heterogenous population. The recent and largest study utilizing at least $80 \%$ pain relief as the criterion standard (24) has shown a prevalence of $39 \%$ in a heterogenous population in a practical setting in the United States. Moreover, this study also showed $95 \%$ confidence intervals of $32 \%$ to $45 \%$, a narrow interval. In another study by the same group of authors (25), the prevalence was shown as $55 \%$. It appears that as with increasing experience and proper selection, the prevalence may be around $40 \%$ rather than $60 \%$ as was shown in earlier studies.

In this assessment, good diagnostic evidence was derived from only the studies utilizing at least $75 \%$ pain relief as the criterion standard with controlled diagnostic blocks $(23-25,27,29,30,32,33,78)$. This evaluation also shows that the validity of accuracy and reliability were evaluated based on diagnostic accuracy and various studies evaluating the factors influencing diagnostic accuracy $(26,28,31,205,206,208-210)$ In fact, the effect of sedation was insignificant in cases with $80 \%$ pain relief as the criterion standard with controlled diagnostic blocks in influencing the diagnosis of facet joint pain, whereas it was significant when $50 \%$ pain relief was used as the criterion standard resulting in a much higher positive response and potentially false-positive results.

Manchikanti et al (26) evaluated the age-related prevalence and false-positive rates of facet joint involvement in chronic neck pain using controlled comparative local anesthetic blocks. Patients were divided into 6 groups with Group I from 18 to 30 years, Group II with 31 to 40 years, Group III from 41 to 50 years, Group IV from 51 to 60 years, Group V from 61 to 70 years, and Group VI over 70 years. The prevalence of cervical facet joint pain was $42 \%$ with a false-positive rate of $40 \%$ in Group I, $35 \%$ and $45 \%$ in Group II, $40 \%$ and $39 \%$ in
Group III, $41 \%$ and $43 \%$ in Group IV, $36 \%$ and $58 \%$ in Group V, and $33 \%$ and $56 \%$ in Group VI. Surprisingly, the lowest prevalence was noted in patients over 70 years of age, followed by patients aged 31 to 40 years with $33 \%$ and $35 \%$.

Psychological factors were evaluated in 2 studies $(31,205)$. The study by Manchikanti et al $(31)$ assessed the influence of psychopathology (depression, generalized anxiety disorder, somatization disorder individually or in combinations of multiple psychopathologic conditions) on the ability of controlled, comparative local anesthetic blocks to accurately identify facet joint pain and false-positive rates with a single block. In the cervical spine, the prevalence was $28 \%$ with a false-positive rate of $58 \%$ in patients with no psychopathology, whereas the prevalence was $43 \%$ with a false-positive rate of $39 \%$ in patients with major depression and $55 \%$ in patients without major depression which was statistically significant; $42 \%$ prevalence and $40 \%$ false-positive rate in patients with generalized anxiety disorder compared to $30 \%$ and $55 \%$ in patients without generalized anxiety disorder; and prevalence was $38 \%$ with a falsepositive rate of $40 \%$ in patients with somatization disorder, whereas it was $39 \%$ and $46 \%$ in patients without somatization disorder. Most importantly, somatization disorder has consistently yielded a greater number of unreliable results. That was not the case in this study. In essence, only the significant differences were noted with prevalence, as well as with false-positive rates in patients with or without major depression ( $43 \%$ vs. $30 \%$ and $39 \%$ vs. $55 \%$ ).

The study by Wasan et al (205) was poorly conducted without appropriate controlled diagnostic blocks and outcome parameters. They described patients with low, moderate, or high levels of psychopathology. The facet joint blocks were performed with a single block with high volumes in a small proportion of patients. The low psychopathology group reported a mean of $23 \%$ improvement in pain at one month, whereas high psychopathology group reported a worsening of $6 \%$ pain. No conclusions could be drawn from this evaluation.

Manchikanti et al (28) also evaluated the prevalence of facet joint pain in postsurgical and non-surgical patients in the cervical spine with controlled comparative local anesthetic blocks. The prevalence of cervical facet joint pain and a false-positive rate of single blocks in postsurgical patients were $36 \%$ and $50 \%$ compared to $39 \%$ and $43 \%$ in non-surgical patients. Thus, there was no difference in the prevalence of these patients in the cervical spine. However, the prevalence of facet 
joint pain in the lumbar spine in postsurgical patients has been shown to be lower in the lumbar spine compared to non-surgical patients $(24,25)$.

In one study, Cohen et al (206) evaluated the influence of low dose and high dose volumes $0.25 \mathrm{~mL}$ or 0.5 $\mathrm{mL}$ of bupivacaine in producing the specific blockade. However, the group with $0.5 \mathrm{~mL}$ showed a prevalence of cervical facet joint pain with positive results of $25 \%$, whereas the low volume group showed a prevalence of $55 \%$ with an injection of $0.25 \mathrm{~mL}$.

Manchikanti et al (210) evaluated the influence of prior opioid exposure on diagnostic facet joint nerve blocks. They assessed patients after categorizing them into 4 groups based on the level of opioid use: Group I with no opioid use, Group II with low opioid use, Group III with moderate opioid use, and Group IV with high opioid use. Controlled, comparative local anesthetic blocks were performed for the diagnosis of facet joint pain. The study showed that prior and current opioid use was not linked to the diagnostic validity of controlled, comparative local anesthetic blocks. In the cervical spine, the prevalence was $33 \%$ in the no opioid group with a false-positive rate of $53 \%$ in contrast to $40 \%$ and $41 \%$ in the low opioid group, $37 \%$ and $45 \%$ in moderate opioid group, and $53 \%$ and $38 \%$ in the high opioid group. Even though the high opioid group appears to be positive in a larger proportion of patients, there were no significant differences noted among the groups. However, it appears that there is a trend of increased prevalence of facet joint pain or at least the diagnosis of prevalence of facet joint pain in patients receiving high opioid dosages. In an evaluation of the role of sedation, 2 studies were conducted evaluating the effect of sedation in the diagnosis of cervical facet joint pain utilizing $80 \%$ pain relief as the criterion standard $(208,209)$. Both studies showed no significant difference when $80 \%$ or higher pain relief was utilized as the criterion standard between placebo, midazolam, and fentanyl, however, the differences became significant when a $50 \%$ criterion standard was used with a significantly high proportion of patients reporting positive results in the fentanyl group. Thus, it is advisable not to use opioids or narcotics during the diagnosis. However, it appears that with the $80 \%$ criterion standard, even fentanyl has no significant influence at the present time based on the present studies $(208,209)$.

Finally, Barnsley et al (245) assessed the utility of randomized, double-blind, controlled, comparative local anesthetic blocks for the diagnosis of cervical zygapophysial joint pain. In this evaluation, the blocks were performed using either lidocaine or bupivacaine, randomly allocated, and the patients' responses were assessed in a double-blind fashion. Any positive response was subsequently assessed by repeating the block with the complementary anesthetic. Only those patients experiencing a longer period of pain relief from the bupivacaine were considered to have truepositive responses. Consequently, the authors concluded that comparative, diagnostic blocks are a valid technique in the identification of painful zygapophysial joints, and constitute an implementable alternative to normal saline controls. Not surprisingly, a subgroup of 13 of 47 patients experienced unexpected prolonged responses to one or both of the local anesthetics. This systematic review illustrates the role of therapeutic cervical facet joint nerve blocks with fair evidence, which was illustrated initially in some patients in 1993 (245). In addition, Lord et al (246) also assessed the utility of comparative local anesthetic blocks versus placebo-controlled blocks for the diagnosis of cervical facet joint pain. Fifty consecutive patients referred for an assessment of chronic neck pain underwent 3 blocks using 3 different agents - lignocaine, bupivacaine, and normal saline - administered on separate occasions, in random order and under double-blind conditions. The diagnostic decision based on comparative blocks alone was compared with the based on placebo-controlled blocks. The results illustrated that comparative local anesthetic blocks were found to have a specificity of $88 \%$, but only marginal sensitivity with $54 \%$. Thus, comparative blocks result in few false-positive diagnoses, but they also may result in a high proportion of false-negative diagnoses. However, this study also showed that expanding the comparative blocks diagnostic criteria to include all patients with reproducible relief, irrespective of duration, increases sensitivity $100 \%$, but lowers the specificity to $65 \%$.

Assessment, grading the quality of evidence and providing recommendations for diagnostic tests and strategies are important in all branches of medicine, but specifically in interventional pain management $(26,28,31,164,165,174,179,180-184,194-203,247)$. Clinicians often use diagnostic tests as a package or strategy. Interventional pain physicians use a diagnostic strategy that includes signs and symptoms and imaging to identify physiological derangements, establish prognosis, monitor illness, and diagnose $(174,175)$. Consequently, it has been recommended by Schünemann et al (174) that guideline panels considering a diagnostic test or strategy should begin by identifying the patients, diagnostic 
intervention (strategy), comparison, and outcomes of interest (176). The accuracy of a diagnostic test based on sensitivity and specificity classifies patients correctly as having or not having a disease. The underlying assumption is, however, that obtaining a better idea of whether a target condition is present or absent will result in an improved outcome. Thus, if a test is already available, a new test presumably with superior accuracy must be tested in a randomized controlled trial (RCT) in which investigators randomize patients to experimental or control diagnostic approaches and measure pain relief, functional status, quality of life improvement, and morbidity (177). To compare the impact of alternative diagnostic strategies on patient-important outcomes, guideline panels can use the Grading of Recommendations Assessment, Development and Evaluation (GRADE) approach $(248,249)$. When such studies are not available, guideline panels must focus on studies of test accuracy and make inferences about the likely impact on patient-important outcomes (178). Thus far in the diagnosis of cervical facet joint pain only one diagnostic strategy is available - controlled diagnostic blocks. This strategy has been proven to be accurate since conventional clinical and radiological techniques, pain patterns, and physical examination findings have been shown to be less than reliable in the diagnosis of facet joint pain (97-142). Even then, controlled comparative local anesthetic blocks have faced significant criticism often based on personal philosophy $(97,101)$., The effect of placebo and nocebo and controversy arising from these effects continues to be misunderstood and widely misinterpreted (250-258). Furthermore, a therapeutic effect has been illustrated with any solution injected into a closed space, such as an intraarticular space, or epidural space, or over a nerve, and this not been appropriately taken into consideration in interpreting the results. In fact, multiple studies have illustrated a significant effect for sodium chloride solution, either injected into the epidural space, intra-articularly, or over the nerves (181,184,258-261). In addition, a multitude of differences have been published with injection of either sodium chloride solution or dextrose, both considered as placebo $(181,184,262-266)$. Further, the consideration of local anesthetic injections as placebo is also questionable, and published evidence shows a multitude of studies showing long lasting effectiveness of local anesthetics, as well as steroids, with many similarities between them (267-298). Factors that decrease the quality of evidence for studies of diagnostic accuracy include study design and risk of bias. Other indirect factors include outcomes, patient populations, diagnostic tests, comparison tests and indirect comparisons, important inconsistencies in study results, imprecise evidence, and a high probability of publication bias $(164,174,165,181-184)$. We have attempted in our systematic review to consider all these aspects with the utilization of appropriate and strict inclusion criteria and methodological quality assessment. However, the weakness continues to be with the lack of a criterion standard based on the tissue biopsy. The criterion standard utilized here that has, yielded the best evidence is a controlled diagnostic block with at least $75 \%$ pain relief and the ability to perform painful movements. This has been supported by significant improvement in patients when the diagnosis was made appropriately and treatment with either medial branch blocks or radiofrequency neurotomy was provided $(34,79,80,94-96)$.

The diagnosis of facet joint pain by controlled local anesthetic blocks is considered as valid. Controlled diagnostic blocks with 2 local anesthetics with placebo control are the only means of confirming the diagnosis of facet joint pain. The face validity of cervical medial branch blocks has been established by injecting small volumes of local anesthetic and contrast material onto the target points. Construct validity of cervical facet joint blocks is important to eliminate placebo effect as a source of confounding results and to secure truepositive results $(23-29,32,33,164,179,183,184)$. Further, the hypothesis that testing a patient first with lidocaine and subsequently with bupivacaine provides a means of identifying that the placebo responses have been tested $(245,246,299)$.

Controlled comparative local anesthetic blocks are easier to implement in a conventional practice and, therefore, are likely to be preferred and used by physicians unable to perform placebo-controlled blocks specifically in the United States. Moreover, when compared with placebo-controlled blocks, the false-positive rate has been shown to be very low (246). Therefore, a diagnosis based on comparative blocks is unlikely to be wrong. Cohen et al (207), by proposing a single block, only strengthened rather than weakened the value of comparative local anesthetic blocks (300). The lack of influence of psychological variables (205), age (26), opioid exposure (210), previous surgery (28), and sedation $(208,209)$ have been published.

Consequently, we believe that the present systematic review provides good evidence in favor of controlled diagnostic blocks in diagnosing cervical facet joint pain with a criterion standard of $75 \%$ pain relief 
and the ability to perform multiple maneuvers which were painful prior to diagnostic blockade.

In conclusion, the evidence is good or strong for accuracy of diagnostic facet joint nerve blocks in the diagnosis of chronic cervical facet joint pain with at least $75 \%$ relief with controlled diagnostic blocks.

\subsection{Conclusion}

Diagnostic cervical facet joint nerve blocks are safe, valid, and reliable. Based on the review of available studies that met inclusion criteria, the strength of evidence for diagnostic facet joint nerve blocks is good with at least $75 \%$ relief with controlled diagnostic blocks.

\section{Acknowledgments}

The authors wish to thank Vidyasagar Pampati, MSc, for statistical assistance, Sekar Edem for assistance in the search of the literature, Alvaro F. Gómez, MA, and Bert Fellows, MA, for manuscript review, and Tonie M. Hatton and Diane E. Neihoff, transcriptionists, for their assistance in preparation of this manuscript. The authors also thank Pain Physician for permitting to reproduce Falco et al's (34) manuscript from 2009. We would like to thank the editorial board of Pain Physician for review and criticism in improving the manuscript.

\section{Author Affiliations}

Dr. Falco is Medical Director of Mid Atlantic Spine \& Pain Physicians, DE; Director, Pain Medicine Fellowship,
Temple University Hospital, Philadelphia, PA and Associate Professor, Department of PM\&R, Temple University Medical School, Philadelphia, PA.

Dr. Datta is Medical Director, Laser Spine \& Pain Institute, New York, NY, and Professorial Lecturer, Mount Sinai School of Medicine, Department of Anesthesiology, New York, NY.

Dr. Manchikanti is Medical Director of the Pain Management Center of Paducah, Paducah, KY and Clinical Professor, Anesthesiology and Perioperative Medicine, University of Louisville, Louisville, KY.

Dr. Sehgal is Medical Director, Interventional Pain Program, University of Wisconsin School of Medicine and Public Health and Associate Professor, Department of Orthopedics and Rehabilitation Medicine, Madison, WI.

Ms. Geffert is Director of Research and Education and Administrative Assistant at Mid Atlantic Spine \& Pain Physicians of Newark, DE and Fellowship Coordinator at Temple University Hospital, Philadelphia, PA.

Dr. Singh is Medical Director, Spine Pain Diagnostics Associates, Niagara, WI.

Dr. Smith is Professor and Academic Director of Pain Management for Albany Medical College Department of Anesthesiology, Albany, NY

Dr. Boswell is Chairman, Department of Anesthesiology and Perioperative Medicine, University of Louisville, Louisville, $\mathrm{KY}$

\section{References}

1. Hogg-Johnson S, van der Velde G, Carroll LJ, Holm LW, Cassidy JD, Guzman J, Côté P, Haldeman S, Ammendolia C, Carragee E, Hurwitz E, Nordin M, Peloso $\mathrm{P}$, Bone and Joint Decade 2000-2010 Task Force on Neck Pain and Its Associated Disorders. The burden and determinants of neck pain in the general population: Results of the Bone and Joint Decade 2000-2010 Task Force on Neck Pain and Its Associated Disorders. Spine (Phila Pa 1976) 2008; 33:S39-S51.

2. Manchikanti L, Boswell MV, Singh V, Benyamin RM, Fellows B, Abdi S, Buenaventura RM, Conn A, Datta S, Derby R, Falco FJE, Erhart S, Diwan S, Hayek SM, Helm S, Parr AT, Schultz DM, Smith
HS, Wolfer LR, Hirsch JA. Comprehensive evidence-based guidelines for interventional techniques in the management of chronic spinal pain. Pain Physician 2009; 12:699-802.

3. Enthoven P, Skargren E, Oberg B. Clinical course in patients seeking primary care for back or neck pain: A prospective 5-year follow-up of outcome and health care consumption with subgroup analysis. Spine (Phila Pa 1976) 2004; 29:24582465.

4. Gustavsson C, Denison E, von Koch L. Self-management of persistent neck pain: Two-year follow-up of a randomized controlled trial of a multicomponent group intervention in primary health care. Spine (Phila Pa 1976) 2011; 36:2105-2015.

5. Guez $M$, Hildingsson $C$, Nilsson $M$, Toolanen G. The prevalence of neck pain: A population-based study from northern Sweden. Acta Orthop Scand 2002; 73:455-459.

6. Côté P, Cassidy JD, Carroll L. The Saskatchewan Health and Back Pain Survey. The prevalence of neck pain and related disability in Saskatchewan adults. Spine (Phila Pa 1976) 1998; 23:1689-1698.

7. Peloso PMJ, Gross A, Haines T, Trinh K, Goldsmith $\mathrm{CH}$, Burnie SJ, Cervical Overview Group. Medicinal and injection therapies for mechanical neck disorders. Cochrane Database Syst Rev 
2007; 3:CDooo319.

8. Linton SJ, Hellsing AL, Hallden K. A population based study of spinal pain among 35-45-year old individuals. Spine (Phila Pa 1976) 1998; 23:1457-1463.

9. Bot SD, van der Waal JM, Terwee CB, van der Windt DA, Schellevis FG, Bouter LM, Dekker J. Incidence and prevalence of complaints of the neck and upper extremity in general practice. Ann Rheum Dis 2005; 64:118-123.

10. Croft PR, Lewis M, Papageorgiou AC, Thomas E, Jayson MI, Macfarlane GJ, Silman AJ. Risk factors for neck pain: A longitudinal study in the general population. Pain 2001; 93:317-325.

11. Côté P, Cassidy JD, Carroll LJ, Kristman $V$. The annual incidence and course of neck pain in the general population: A population-based cohort study. Pain 2004; 112:267-273.

12. Leboeuf-Yde C, Nielsen J, Kyvik KO, Fejer R, Hartvigsen J. Pain in the lumbar, thoracic or cervical regions: Do age and gender matter? A population-based study of 34,902 Danish twins 20-71 years of age. BMC Musculoskelet Disord 2009; 10:39.

13. Leboeuf-Yde C, Fejer R, Nielsen J, Kyvik $\mathrm{KO}$, Hartvigsen J. Consequences of spinal pain: do age and gender matter? A Danish cross-sectional populationbased study of 34,902 individuals 20-71 years of age. BMC Musculoskelet Disord 2011; 12:39.

14. Côté $P$, Kristman V, Vidmar M, Van Eerd D, Hogg-Johnson S, Beaton D, Smith PM. The prevalence and incidence of work absenteeism involving neck pain: A cohort of Ontario lost-time claimants. Spine (Phila Pa 1976) 2008; 33:S192-S198.

15. Cassidy JD, Carroll LJ, Côté P, Lemstra M, Berglund A, Nygren A. Effect of eliminating compensation for pain and suffering on the outcome of insurance claims for whiplash injury. $N$ Engl J Med 2000; 342:1179-1186.

16. Radanov BP, Sturzenegger M, De Stefano G, Schnidrig A. Relationship between early somatic, radiological, cognitive and psychosocial findings and outcome during a one-year follow-up in 117 patients suffering from common whiplash. Br J Rheumatol 1994; 33:442-448.

17. Bogduk N. The anatomy and pathophysiology of neck pain. Phys Med Rehabil Clin N Am 2011; 22:367-382.

18. Schoenfeld AJ, George AA, Bader JO, Caram PM Jr. Incidence and epidemiology of cervical radiculopathy in the
United States military: 2000 to 2009 . J

Spinal Disord Tech 2012; 25:17-22.

19. Côté P, van der Velde G, Cassidy JD, Carroll LJ, Hogg-Johnson S, Holm LW, Carragee EJ, Haldeman S, Nordin M, Hurwitz EL, Guzman J, Peloso PM, Bone and Joint Decade 2000-2010 Task Force on Neck Pain and Its Associated Disorders. The burden and determinants of neck pain in workers. Results of the Bone and Joint Decade 2000-2010 Task Force on Neck Pain and Its Associated Disorders. Spine (Phila Pa 1976) 2008; 33:S60-S74.

20. Palmer KT, Walker-Bone $\mathrm{K}$, Griffin $\mathrm{MJ}$, Syddall H, Pannett B, Coggon D, Cooper $C$. Prevalence and occupational associations of neck pain in the British population. Scand J Work Environ Health 2001; 27:49-56.

21. Van Zundert J, Harney D, Joosten EA, Durieux ME, Patijn J, Prins MH, Van Kleef $\mathrm{M}$. The role of the dorsal root ganglion in cervical radicular pain: diagnosis, pathophysiology, and rationale for treatment. Reg Anesth Pain Med 2006; 31:152-167.

22. Howe JF, Loeser JD, Calvin WH. Mechanosensitivity of dorsal root ganglia and chronically injured axons: A physiological basis for the radicular pain of nerve root compression. Pain 1977; 3:25-41.

23. Yin W, Bogduk N. The nature of neck pain in a private pain clinic in the United States. Pain Med 2008; 9:196-203.

24. Manchukonda R, Manchikanti KN, Cash KA, Pampati V, Manchikanti L. Facet joint pain in chronic spinal pain: An evaluation of prevalence and false-positive rate of diagnostic blocks. J Spina Disord Tech 2007; 20:539-545.

25. Manchikanti L, Boswell MV, Singh $V$, Pampati V, Damron KS, Beyer CD. Prevalence of facet joint pain in chronic spinal pain of cervical, thoracic, and lumbar regions. BMC Musculoskelet Disord 2004; 5:15.

26. Manchikanti L, Manchikanti K, Cash KA, Singh V, Giordano J. Age-related prevalence of facet joint involvement in chronic neck and low back pain. Pain Physician 2008; 11:67-75.

27. Manchikanti L, Singh V, Pampati V, Damron KS, Beyer CD, Barnhill RC. Is there correlation of facet joint pain in lumbar and cervical spine? An evaluation of prevalence in combined chronic low back and neck pain. Pain Physician 2002; 5:365-371.

28. Manchikanti L, Manchikanti K, Pampa- ti V, Brandon D, Giordano J. The prevalence of facet joint-related chronic neck pain in postsurgical and non-postsurgical patients: A comparative evaluation. Pain Pract 2008; 8:5-10.

29. Manchikanti L, Singh V, Rivera J, Pampati V. Prevalence of cervical facet joint pain in chronic neck pain. Pain Physician 2002; 5:243-249.

30. Speldewinde G, Bashford G, Davidson I. Diagnostic cervical zygapophyseal joint blocks for chronic cervical pain. Med ] Aust 2001; 174:174-176.

31. Manchikanti L, Cash K, Pampati V, Fellows $B$. Influence of psychological variables on the diagnosis of facet joint involvement in chronic spinal pain. Pain Physician 2008; 11:145-160.

32. Barnsley L, Lord SM, Wallis BJ, Bogduk $N$. The prevalence of chronic cervical zygapophyseal joint pain after whiplash. Spine (Phila Pa 1976) 1995; 20:20-26.

33. Lord SM, Barnsley L, Wallis BJ, Bogduk N. Chronic cervical zygapophysial joint pain with whiplash: A placebo-controlled prevalence study. Spine (Phila Pa 1976) 1996; 21:1737-1744.

34. Falco FJ, Erhart S, Wargo BW, Bryce DA, Atluri S, Datta S, Hayek SM. Systematic review of diagnostic utility and therapeutic effectiveness of cervical facet joint interventions. Pain Physician 2009; 12:323-344.

35. Dwyer A, Aprill C, Bogduk N. Cervical zygapophyseal joint pain patterns: A study in normal volunteers. Spine (Phila $\mathrm{Pa}$ 1976) 1990; 15:453-457.

36. Aprill C, Dwyer A, Bogduk N. The prevalence of cervical zygapophyseal joint pain patterns II: A clinical evaluation. Spine (Phila Pa 1976) 1990; 15:458-461.

37. Fukui S, Ohseto K, Shiotani M, Ohno K, Karasawa H, Naganuma Y, Yuda Y. Referred pain distribution of the cervical zygapophyseal joints and cervical dorsal rami. Pain 1996; 68:79-83.

38. Pawl RP. Headache, cervical spondylosis, and anterior cervical fusion. Surg Ann 1977; 9:391-498.

39. Windsor RE, Nagula D, Storm S. Electrical stimulation induced cervical medial branch referral patterns. Pain Physician 2003; 6:411-418.

40. Bogduk N. The clinical anatomy of the cervical dorsal rami. Spine (Phila Pa 1976) 1982; 7:319-330.

41. Ohtori S, Takahashi K, Chiba T, Yamagata M, Sameda H, Moriya H. Sensory innervation of the cervical facet joints in rats. Spine (Phila Pa 1976) 2001; 26:147- 
150.

42. Cavanaugh JM, Lu Y, Chen C, Kallakuri $S$. Pain generation in lumbar and cervical facet joints. J Bone Joint Surg Am 2006; 88:63-67.

43. Barnsley L, Bogduk N. Medial branch blocks are specific for the diagnosis of cervical zygapophyseal joint pain. Reg Anesth 1993; 18:343-350.

44. Zhang J, Tsuzuki N, Hirabayashi S, Saiki K, Fujita K. Surgical anatomy of the nerves and muscles in the posterior cervical spine. Spine (Phila Pa 1976) 2003; 1379-1384.

45. Siegenthaler A, Schliessbach J, Curatolo $\mathrm{M}$, Eichenberger U. Ultrasound anatomy of the nerves supplying the cervical zygapophyseal joints: An exploratory study. Reg Anesth Pain Med 2011; 36:606610.

46. Kallakuri S, Li Y, Chen C, Cavanaugh JM. Innervation of cervical ventral facet joint capsule: Histological evidence. World J Orthop 2012; 3:10-14.

47. Chen C, Lu Y, Cavanaugh JM, Kallakur $S$, Patwardhan A. Recording of neural activity from goat cervical facet joint capsule using custom-designed miniature electrodes. Spine (Phila Pa 1976) 2006; 30:1367-1672.

48. Lu Y, Chen C, Kallakuri S. Patwardhan A, Cavanaugh JM. Neurophysiological and biomechanical characterization of goat cervical facet joint capsules. ] Orthop Res 2005; 30:779-787.

49. Inami S, Shiga T, Tsujino A, Yabuki T, Okado N, Ochiai N. Immunohistochemical demonstration of nerve fibers in the synovial fold of the human cervical facet joint. J Orthop Res 2001; 19:593596.

50. Chen C, Lu Y, Kallakuri S, Patwardhan A, Cavanaugh JM. Distribution of A-delta and C-fiber receptors in the cervical facet joint capsule and their response to stretch. J Bone Joint Surg Am 2006; 88:1087-1816.

51. Kallakuri S, Singh A, Chen C, Cavanaugh JM. Demonstration of substance $P$, calcitonin gene-related peptide, and protein gene product 9.5 containing nerve fibers in human cervical facet joint capsules. Spine (Phila Pa 1976) 2004; 29:11821186.

52. McLain RF. Mechanoreceptors ending in human cervical facets joints. Spine (Phila Pa 1976) 1994; 5:495-501.

53. Winkelstein BA, Santos DG. An intact facet capsular ligament modulates behavioral sensitivity and spinal glial ac- tivation produced by cervical facet joint tension. Spine (Phila Pa 1976). 2008; 33:856-862.

54. Lee KE, Davis MB, Mejilla RM, Winkelstein BA. In vivo cervical facet capsule distraction: Mechanical implications for whiplash and neck pain. Stapp Car Crash J 2004; 48:373-395.

55. Lee KE, Thinnes JH, Gokhin DS, Winkelstein BA. A novel rodent neck pain model of facet-mediated behavioral hypersensitivity: Implications for persistent pain and whiplash injury. ] Neurosci Methods 2004; 137:151-159.

56. Schneider GM, Smith AD, Hooper A Stratford P, Schneider KJ, Westaway MD, Frizzell B, Olson L. Minimizing the source of nociception and its concurrent effect on sensory hypersensitivity: An exploratory study in chronic whiplash patients. BMC Musculoskelet Disord 2010; 11:29.

57. Chua $\mathrm{NH}$, van Suijlekom HA, Vissers KC, Arendt-Nielsen L, Wilder-Smith $\mathrm{OH}$. Differences in sensory processing between chronic cervical zygapophysial joint pain patients with and without cervicogenic headache. Cephalalgia 2011; 31:953-963.

58. Quinn KP, Dong L, Golder FJ, Winkelstein BA. Neuronal hyperexcitability in the dorsal horn after painful facet joint injury. Pain 2010; 151:414-421.

59. Dong L, Odeleye AO, Jordan-Sciutto KL, Winkelstein BA. Painful facet joint injury induces neuronal stress activation in the DRG: implications for cellular mechanisms of pain. Neurosci Lett 2008; 443:90-94.

6o. Dong L, Winkelstein BA. Simulated whiplash modulates expression of the glutamatergic system in the spinal cord suggesting spinal plasticity is associated with painful dynamic cervical facet loading. J Neurotrauma 2010; 27:163-174.

61. Kettler A, Werner K, Wilke HJ. Morphological changes of cervical facet joints in elderly individuals. Eur Spine J 2007; 16:987-992.

62. Uhrenholt L, Hauge E, Charles AV, Gregersen $M$. Degenerative and traumatic changes in the lower cervical spine facet joints. Scand J Rheumatol 2008; 37:375384 .

63. Abd Latif MJ, Jin Z, Wilcox RK. Biomechanical characterisation of ovine spinal facet joint cartilage. ] Biomech 2012; 45:1346-1352.

64. Wilke HJ, Zanker D, Wolfram U. Inter- nal morphology of human facet joints: Comparing cervical and lumbar spine with regard to age, gender and the vertebral core. J Anat 2012; 220:233-241.

65. Webb AL, Rassoulian H, Mitchell BS. Morphometry of the synovial folds of the lateral atlanto-axial joints: The anatomical basis for understanding their potential role in neck pain. Surg Radiol Anat 2012; 34:115-124.

66. Li J, Muehleman C, Abe Y, Masuda K. Prevalence of facet joint degeneration in association with intervertebral joint degeneration in a sample of organ donors. J Orthop Res 2011; 29:1267-1274.

67. Webb AL, Collins P, Rassoulian $H$, Mitchell BS. Synovial folds - a pain in the neck? Man Ther 2011; 16:118-124.

68. Lee MJ, Riew KD. The prevalence cervical facet arthrosis: An osseous study in a cadveric population. Spine ] 2009; 9:711714 .

69. Uhrenholt L, Charles AV, Hauge E, Gregersen M. Pathoanatomy of the lower cervical spine facet joints in motor vehicle crash fatalities. J Forensic Leg Med 2009; 16:253-26o.

70. Uhrenholt L, Nielsen E, Charles AV, Gregersen M. Non-fatal injuries to the cervical spine facet joints after a fatal motor vehicle crash: A case report. Med Sci Law 2009; 49:218-221.

71. Morishita K, Kasai Y, Uchida A. Hypertrophic change of facet joint in the cervical spine. Med Sci Monit 2008; 14:CR62CR64.

72. Kallakuri S, Singh A, Lu Y, Chen C, Patwardhan A, Cavanaugh JM. Tensile stretching of cervical facet joint capsule and related axonal changes. Eur Spine ] 2008; 17:556-563.

73. Ivancic PC, Ito S, Tominaga Y, Rubin W, Coe MP, Ndu AB, Carlson EJ, Panjabi MM. Whiplash causes increased laxity of cervical capsular ligament. Clin Biomech (Bristol, Avon) 2008; 23:159-165.

74. Bogduk N. On cervical zygapophysial joint pain after whiplash. Spine (Phila Pa 1976) 2011; 36:S194-S199.

75. Curatolo $M$, Bogduk $N$, Ivancic PC, McLean SA, Siegmund GP, Winkelstein BA. The role of tissue damage in whiplash-associated disorders: Discussion paper 1. Spine (Phila Pa 1976) 2011; 36:S309-S315.

76. Hall T, Briffa K, Hopper D. The influence of lower cervical joint pain on range of motion and interpretation of the flexion-rotation test. J Man Manip Ther 2010; 
18:126-1231.

77. Javanshir K, Ortega-Santiago R, Mohseni-Bandpei MA, Miangolarra-Page JC, Fernández-de-Las-Peñas C. Exploration of somatosensory impairments in subjects with mechanical idiopathic neck pain: A preliminary study. J Manipulative Physiol Ther 2010; 33:493-499.

78. Barnsley L, Lord S, Wallis B, Bogduk N. False-positive rates of cervical zygapophysial joint blocks. Clin J Pain 1993; 9:124-130.

79. Pampati S, Cash KA, Manchikanti L. Accuracy of diagnostic lumbar facet joint nerve blocks: A 2-year follow-up of 152 patients diagnosed with controlled diagnostic blocks. Pain Physician 2009; 12:855-866.

8o. Manchikanti L, Pampati S, Cash KA. Making sense of the accuracy of diagnostic lumbar facet joint nerve blocks: An assessment of implications of 50\% relief, $80 \%$ relief, single block or controlled diagnostic blocks. Pain Physician 2010; 13:133-143.

81. Chua NH, Vissers KC, Arendt-Nielsen L, Wilder-Smith $\mathrm{OH}$. Do diagnostic blocks have beneficial effects on pain processing? Reg Anesth Pain Med 2011; 36:317321.

82. Rubinstein SM, van Tulder M. A best-evidence review of diagnostic procedures for neck and low-back pain. Best Pract Res Clin Rheumatol 2008; 22:471-482.

83. Geurts JW, van Wijk RM, Stolker RJ, Groen G]. Efficacy of radiofrequency procedures for the treatment of spinal pain: A systematic review of randomized clinical trials. Reg Anesth Pain Med 2001; 26:394-400.

84. Niemistö L, Kalso E, Malmivaara A, Seitsalo $\mathrm{S}$, Hurri H, Cochrane Collaboration Back Review Group. Radiofrequency denervation for neck and back pain: A systematic review within the framework of the Cochrane collaboration back review group. Spine (Phila Pa 1976) 2003; 28:1877-1888.

85. Manchikanti L, Singh V, Vilims BD, Hansen HC, Schultz DM, Kloth DS. Medial branch neurotomy in management of chronic spinal pain: Systematic review of the evidence. Pain Physician 2002; 5:405-418.

86. Husted DS, Orton D, Schofferman J, Kine G. Effectiveness of repeated radiofrequency neurotomy for cervical facet joint pain. J Spinal Disord Tech 2008; 21:406-408.
87. Liliang PC, Lu K, Hsieh $\mathrm{CH}$, Kao CY, Wang KW, Chen HJ. Pulsed radiofrequency of cervical medial branches for treatment of whiplash-related cervical zygapophysial joint pain. Surg Neurol 2008; 70:S1:50-55; discussion S1:55.

88. Lang JK, Buchfelder M. Radiofrequency neurotomy for headache stemming from the zygapophysial joints $C_{2} / 3$ and C3/4. Cent Eur Neurosurg 2010; 71:75-79.

89. Speldewinde GC. Outcomes of percutaneous zygapophysial and sacroiliac joint neurotomy in a community setting. Pain Med 2011; 12:209-218.

90. Saayman L, Hay C, Abrahamse H. Chiropractic manipulative therapy and lowlevel laser therapy in the management of cervical facet dysfunction: A randomized controlled study. J Manipulative Physiol Ther 2011; 34:153-163.

91. Chua NH, Vissers KC, Sluijter ME. Pulsed radiofrequency treatment in interventional pain management: Mechanisms and potential indications-a review. Acta Neurochir (Wien) 2011; 153:763771.

92. Barnsley L, Lord SM, Wallis BJ, Bogduk $N$. Lack of effect of intra-articular corticosteroids for chronic pain in the cervical zygapophyseal joints. N Engl J Med 1994; 330:1047-1050.

93. Manchikanti L, Singh V, Falco FJE, Cash KA, Fellows B. Comparative outcomes of a 2-year follow-up of cervical medial branch blocks in management of chronic neck pain: A randomized, double-blind controlled trial. Pain Physician 2010; 13:437-450.

94. Lord S, Barnsley L, Wallis B, McDonald G, Bogduk N. Percutaneous radiofrequency neurotomy for chronic cervical zygapophyseal-joint pain. $N$ Engl J Med 1996; 335:1721-1726.

95. Sapir DA, Gorup JM. Radiofrequency medial branch neurotomy in litigant and non-litigant patients with cervical whiplash. Spine (Phila Pa 1976) 2001; 26:E268-E273.

96. McDonald G, Lord S, Bogduk N. Longterm follow-up of patients treated with cervical radiofrequency neurotomy for chronic spinal pain. Neurosurgery 1999; 45:61-67.

97. Nordin M, Carragee EJ, Hogg-Johnson S, Weiner SS, Hurwitz EL, Peloso PM, Guzman J, van der Velde G, Carroll LJ, Holm LW, Côté P, Cassidy JD, Haldeman $S$. Assessment of neck pain and its associated disorders: results of the Bone and Joint Decade 2000-2010 Task Force on
Neck Pain and Its Associated Disorders. J Manipulative Physiol Ther 2009; 32:S117Si40.

98. Don AS, Carragee EJ. Is the self-reported history accurate in patients with persistent axial pain after a motor vehicle accident? Spine J 2009; 9:4-12.

99. Carragee EJ. Validity of self-reported history in patients with acute back or neck pain after motor vehicle accidents. Spine J 2008; 8:311-319.

10o. King W, Lau P, Lees R, Bogduk N. The validity of manual examination in assessing patients with neck pain. Spine J 2007; 7:22-26.

101. Carragee EJ, Haldeman S, Hurwtiz E. The pyrite standard: The Midas touch in the diagnosis of axial pain syndromes. Spine J 2007; 7:27-31.

102. Siegenthaler $A$, Eichenberger $U$, Schmidlin K, Arendt-Nielsen L, Curatolo $M$. What does local tenderness say about the origin of pain? An investigation of cervical zygapophysial joint pain. Anesth Analg 2010; 110:923-927.

103. Myburgh C, Larsen AH, Hartvigsen J. A systematic, critical review of manual palpation for identifying myofascial trigger points: Evidence and clinical significance. Arch Phys Med Rehabil 2008; 89:1169-1176.

104. Pool JJ, Hoving JL, de Vet HC, van Mameren $H$, Bouter LM. The interexaminer reproducibility of physical examination of the cervical spine. J Manipulative Physiol Ther 2004; 27:84-90.

105. Ylinen J, Takala EP, Kautiainen $\mathrm{H}$, Nykänen $M$, Häkkinen A, Pohjolainen T, Karppi SL, Airaksinen O. Association of neck pain, disability and neck pain during maximal effort with neck muscle strength and range of movement in women with chronic non-specific neck pain. Eur J Pain 2004; 8:473-478.

106. Hoving JL, Pool J, van Mameren $\mathrm{H}$, Devillé WJ, Assendelft WJ, de Vet HC, de Winter AF, Koes BW, Bouter LM. Reproducibility of cervical range of motion in patients with neck pain. BMC Musculoskelet Disord 2005; 6:59.

107. Jordan A, Mehlsen J, Ostergaard K. A comparison of physical characteristics between patients seeking treatment for neck pain and age-matched healthy people. J Manipulative Physiol Ther 1997; 20:468-475.

108. Olson SL, O'Connor DP, Birmingham G, Broman P, Herrera L. Tender point sensitivity, range of motion, and perceived disability in subjects with neck 
pain. J Orthop Sports Phys Ther 2000; 30:13-20.

109. Wainner RS, Fritz JM, Irrgang JJ, Boninger ML, Delitto A, Allison S. Reliability and diagnostic accuracy of the clinical examination and patient self-report measures for cervical radiculopathy. Spine (Phila Pa 1976) 2003; 28:52-62.

110. Hagen KB, Harms-Ringdahl K, Enger $\mathrm{NO}$, Hedenstad R, Morten H. Relationship between subjective neck disorders and cervical spine mobility and motionrelated pain in male machine operators. Spine (Phila Pa 1976) 1997; 22:1501-1507.

111. Larsson B, Björk J, Elert J, Gerdle B. Mechanical performance and electromyography during repeated maximal isokinetic shoulder forward flexions in female cleaners with and without myalgia of the trapezius muscle and in healthy controls. Eur J Appl Physiol 2000; 83:257267.

112. Schneider GM, Jull G, Thomas K, Salo P. Screening of patients suitable for diagnostic cervical facet joint blocks--a role for physiotherapists. Man Ther 2012; 17:180-183.

113. Kalichman L, Kim DH, Li L, Guermazi A, Hunter DJ. Computed tomographyevaluated features of spinal degeneration: prevalence, intercorrelation, and association with self-reported low back pain. Spine ] 2010; 10:200-208.

114. de Koning $\mathrm{CH}$, van den Heuvel SP, Staal JB, Smits-Engelsman BC, Hendriks EJ. Clinimetric evaluation of active range of motion measures in patients with nonspecific neck pain: A systematic review. Eur Spine J 2008; 17:905-921.

115. Williams $M$, Williamson $E$, Gates $S$, Lamb S, Cooke M. A systematic literature review of physical prognostic factors for the development of late whiplash syndrome. Spine (Phila Pa 1976) 2007; 32:E764-E780.

116. Matsumoto $M$, Fujimura $Y$, Suzuki $N$, Nishi $Y$, Nakamura M, Yabe $Y$, Shiga $H$. MRI of cervical intervertebral discs in asymptomatic subjects. J Bone Joint Surg $\mathrm{Br}$ 1998; 80:19-24.

117. Boden SD, McCowin PR, Davis DO, Dina TS, Mark AS, Wiesel S. Abnormal magnetic-resonance scans of the cervical spine in asymptomatic subjects. A prospective investigation. J Bone Joint Surg Am 1990; 72:1178-1184.

118. Siivola SM, Levoska S, Tervonen O, Ilkko $\mathrm{E}$, Vanharanta $\mathrm{H}$, Keinänen-Kiukaanniemi S. MRI changes of cervical spine in asymptomatic and symptomatic young adults. Eur Spine J 2002; 11:358-363.

119. Kato F, Yukawa Y, Suda K, Yamagata M, Ueta T. Normal morphology, age-related changes and abnormal findings of the cervical spine. Part II: Magnetic resonance imaging of over 1,200 asymptomatic subjects. Eur Spine J 2012; 21:1499-1507.

120. Kerkovský M, Bednarík J, Dušek L, Sprláková-Puková $A$, Urbánek I, Mechl M, Válek V, Kadanka Z. Magnetic resonance diffusion tensor imaging in patients with cervical spondylotic spinal cord compression: Correlations between clinical and electrophysiological findings. Spine (Phila Pa 1976) 2012; 37:48-56.

121. Okada E, Matsumoto M, Fujiwara $H$, Toyama Y. Disc degeneration of cervical spine on MRI in patients with lumbar disc herniation: Comparison study with asymptomatic volunteers. Eur Spine J 2011; 20:585-591.

122. Yukawa $Y$, Kato F, Suda K, Yamagata $M$, Ueta T. Age-related changes in osseous anatomy, alignment, and range of motion of the cervical spine. Part I: Radiographic data from over 1,200 asymptomatic subjects. Eur Spine J 2012; 21:1492-1498.

123. Morishita $\mathrm{Y}, \mathrm{Naito} \mathrm{M}$, Hymanson $\mathrm{H}, \mathrm{Mi}$ yazaki M, Wu G, Wang JC. The relationship between the cervical spinal canal diameter and the pathological changes in the cervical spine. Eur Spine J 2009; 18:877-883.

124. Okada $E$, Matsumoto $M$, Ichihara $D$, Chiba K, Toyama Y, Fujiwara H, Momoshima S, Nishiwaki $Y$, Hashimoto $T$, Ogawa J, Watanabe M, Takahata T. Aging of the cervical spine in healthy volunteers: A 10-year longitudinal magnetic resonance imaging study. Spine (Phila Pa 976) 2009; 34:706-712.

125. Fryer G, Adams JH. Magnetic resonance imaging of subjects with acute unilateral neck pain and restricted motion: A prospective case series. Spine J 2011; 11:171-176.

126. Uhrenholt L, Nielsen E, Charles AV, Hauge E, Gregersen M. Imaging occult lesions in the cervical spine facet joints. Am J Forensic Med Pathol 2009; 30:142147.

127. Grauer JN, Vaccaro AR, Lee JY, Nassr A, Dvorak MF, Harrop JS, Dailey AT, Shaffrey $\mathrm{Cl}$, Arnold PM, Brodke DS, Rampersaud R. The timing and influence of $M R I$ on the management of patients with cervical facet dislocations remains highly variable: A survey of members of the Spine Trauma Study Group. J Spinal Disord Tech 2009; 22:96-99.

128. Barboza R, Fox JH, Shaffer LE, Opalek JM, Farooki S. Incidental findings in the cervical spine at CT for trauma evaluation. AJR Am J Roentgenol 2009; 192:725729.

129. Kaabar W, Daar E, Gundogdu O, Jenneson PM, Farquharson MJ, Webb $M$, Jeynes C, Bradley DA. Metal deposition at the bone-cartilage interface in articular cartilage. Appl Radiat Isot 2009; 67:475-479.

130. Coskun O, Ucler S, Karakurum B, Atasoy HT, Yildirim T, Ozkan S, Inan LE. Magnetic resonance imaging of patients with cervicogenic headache. Cephalalgia 2003; 23:842-845.

131. Makki D, Khazim R, Zaidan AA, Ravi K, Toma T. Single photon emission computerized tomography (SPECT) scanpositive facet joints and other spinal structures in a hospital-wide population with spinal pain. Spine J 2010; 10:58-62.

132. Kim KY, Wang MY. Magnetic resonance image-based morphological predictors of single photon emission computed tomography-positive facet arthropathy in patients with axial back pain. Neurosurgery 2006; 59:147-156; discussion 147156.

133. Holder LE, Machin JL, Asdourian PL, Links JM, Sexton CC. Planar and highresolution SPECT bone imaging in the diagnosis of facet syndrome. J Nucl Med 1995; 36:37-44.

134. McDonald M, Cooper R, Wang MY. Use of computed tomography-single-photon emission computed tomography fusion for diagnosing painful facet arthropathy. Technical note. Neurosurg Focus 2007; 22:E2.

135. Hephzibah J, Theodore B, Oommen R, David K, Moses V, Shah S, Panicker J. Use of single-photon emission computed tomography/low-resolution computed tomography fusion imaging in detecting an unusually presenting osteoid osteoma of the lumbar vertebra. Am J Orthop (Belle Mead NJ) 2009; 38:117-119.

136. Gamie S, El-Maghraby T. The role of PET/CT in evaluation of Facet and Disc abnormalities in patients with low back pain using (18)F-Fluoride. Nucl Med Rev Cent East Eur 2008; 11:17-21.

137. Chung CT, Wang CF, Chou CS, Wang SJ, $\mathrm{Kao} \mathrm{CH}$, Lan HC. Single photon emission computed tomography (SPECT) for low back pain induced by extension with 
no root sign. J Chin Med Assoc 2004; 67:349-354.

138. Chiu TT, Lam TH, Hedley AJ. Psychometric properties of a generic health measure in patients with neck pain. Clin Rehabil 2005; 19:505-513.

139. Wlodyka-Demaille S, Poiraudeau S, Catanzariti JF, Rannou F, Fermanian J, Revel $M$. The ability to change of three questionnaires for neck pain. Spine (Phila $\mathrm{Pa}$ 1976) 2004; 71:317-326.

140. Bicer A, Yazici A, Camdeviren H, Erdogan $C$. Assessment of pain and disability in patients with chronic neck pain: reliability and construct validity of the Turkish version of the neck pain and disability scale. Disabil Rehabil 2004; 26:959962.

141. Pinfold M, Niere KR, O'Leary EF, Hoving JL, Green S, Buchbinder R. Validity and internal consistency of a whiplashspecific disability measure. Spine (Phila $\mathrm{Pa}$ 1976) 2004; 29:263-268.

142. Salt E, Wright C, Kelly S, Dean A. A systematic literature review on the effectiveness of non-invasive therapy for cervicobrachial pain. Man Ther 2011; 16:5365.

143. Flórez-García M, Ceberio-Balda F, Morera-Domínguez $C$, Masramón $X$, Pérez $M$. Effect of pregabalin in the treatment of refractory neck pain: Cost and clinical evidence from medical practice in orthopedic surgery and rehabilitation clinics. Pain Pract 2011; 11:369380.

144. Patil PG, Turner DA, Pietrobon R. National trends in surgical procedures for degenerative cervical spine disease: 1990-2000. Neurosurgery 2005; 57:753$75^{8}$.

145. Manchikanti L, Ailinani $\mathrm{H}$, Koyyalagunta D, Datta S, Singh V, Eriator I, Sehgal N, Shah RV, Benyamin RM, Vallejo R, Fellows B, Christo PJ. A systematic review of randomized trials of long-term opioid management for chronic non-cancer pain. Pain Physician 2011; 14:91-121.

146. Manchikanti L, Fellows B, Ailinani H, Pampati V. Therapeutic use, abuse, and nonmedical use of opioids: A ten-year perspective. Pain Physician 2010; 13:401435 .

147. Manchikanti L, Hirsch JA. Medicare physician payment rules for 2011: A primer for the neurointerventionalist. AJNR Am J Neuroradiol 2011; 32:E101-E104.

148. Manchikanti L, Caraway DL, Parr AT, Fellows B, Hirsch JA. Patient Protection and Affordable Care Act of 2010: Re- forming health care reform for the new decade. Pain Physician 2011; 14:35-E67.

149. Manchikanti L, Parr AT, Singh V, Fellows B. Ambulatory surgery centers and interventional techniques: A look at long-term survival. Pain Physician 2011; 14:E177-E215.

150. Manchikanti L, Pampati V, Falco FJE Hirsch JA. Growth of spinal interventional pain management techniques: Analysis of utilization trends and medicare expenditures 2000 to 2008. Spine (Phila Pa 1976) 2012 July 11 [Epub ahead of print].

151. Manchikanti L, Pampati V, Singh V, Boswell MV, Smith HS, Hirsch JA. Explosive growth of facet joint interventions in the Medicare population in the United States: A comparative evaluation of 1997, 2002, and 2006 data. BMC Health Serv Res 2010; 10:84.

152. Manchikanti L, Hirsch JA. Medicare physician payment rules for 2011: A primer for the neurointerventionalist. J Neurointervent Surg 2011; 3:399-402.

153. Manchikanti L, Pampati V, Boswell MV, Smith HS, Hirsch JA. Analysis of the growth of epidural injections and costs in the Medicare population: A comparative evaluation of 1997, 2002, and 2006 data. Pain Physician 2010; 13:199-212.

154. Abbott ZI, Nair KV, Allen RR, Akuthota VR. Utilization characteristics of spinal interventions. Spine ] 2012; 1:35-43.

155. White AP, Arnold PM, Norvell DC, Ecker E, Fehlings MG. Pharmacologic management of chronic low back pain: Synthesis of the evidence. Spine (Phila $\mathrm{Pa}$ 1976) 2011; 36:S131-S143.

156. US Department of Health and $\mathrm{Hu}$ man Services. Office of Inspector General (OIG). Medicare Payments for Facet Joint Injection Services (OEI-05-0700200). September 2008. www.oig.hhs. gov/oei/reports/oei-05-07-00200.pdf

157. Barnsley L. Percutaneous radiofrequency neurotomy for chronic neck pain: Outcomes in a series of consecutive patients. Pain Med 2005; 6:282-286.

158. Park SC, Kim KH. Effect of adding cervical facet joint injections in a multimodal treatment program for long-standing cervical myofascial pain syndrome with referral pain patterns of cervical facet joint syndrome. J Anesth 2012 May 31. [Epub ahead of print]

159. Aprill C, Bogduk N. The prevalence of cervical zygapophyseal joint pain. A first approximation. Spine (Phila $\mathrm{Pa}$ 1976) 1992; 17:744-747.
160. Park SW, Park YS, Nam TK, Cho TG. The effect of radiofrequency neurotomy of lower cervical medial branches on cervicogenic headache. J Korean Neurosurg Soc 2011; 50:507-511.

161. Shojania KG, Sampson M, Ansari MT, Ji J, Doucette S, Moher D. How quickly do systematic reviews go out of date? A survival analysis. Ann Intern Med 2007; 147:224-233.

162. Sampson M, Shojania KG, Garritty C, Horsley T, Ocampo M, Moher D. Systematic reviews can be produced and published faster. J Clin Epidemiol 2008; 61:531-536.

163. Hancock MJ, Maher CG, Latimer J, Spindler MF, McAuley JH, Laslett M, Bogduk $\mathrm{N}$ : Systematic review of tests to identify the disc, SIJ or facet joint as the source of low back pain. Eur Spine J 2007; 16:1539-1550.

164. Manchikanti L, Datta S, Derby R, Wolfer LR, Benyamin RM, Hirsch JA. A critical review of the American Pain Society clinical practice guidelines for interventional techniques: Part 1. Diagnostic interventions. Pain Physician 2010; 13:E141E174.

165. Manchikanti L, Datta S, Gupta S, Munglani R, Bryce DA, Ward SP, Benyamin RM, Sharma ML, Helm II S, Fellows B, Hirsch JA. A critical review of the American Pain Society clinical practice guidelines for interventional techniques: Part 2. Therapeutic interventions. Pain Physician 2010; 13:E215-E264.

166. Lucas N, Macaskill P, Irwig L, Moran R, Bogduk N. Reliability of physical examination for diagnosis of myofascial trigger points: A systematic review of the literature. Clin J Pain 2009; 25:80-89.

167. Lucas NP, Macaskill P, Irwig L, Bogduk $N$. The development of a quality appraisal tool for studies of diagnostic reliability (QAREL). J Clin Epidemiol 2010; 63:854-861.

168. Manchikanti L, Derby R, Wolfer LR, Singh V, Datta S, Hirsch JA. Evidencebased medicine, systematic reviews, and guidelines in interventional pain management: Part 5. Diagnostic accuracy studies. Pain Physician 2009; 12:517-540.

169. Manchikanti L, Derby R, Wolfer LR, Singh V, Datta S, Hirsch JA. Evidencebased medicine, systematic reviews, and guidelines in interventional pain management: Part 7: Systematic reviews and meta-analyses of diagnostic accuracy studies. Pain Physician 2009; 12:929-963. 170. Bossuyt PM, Reitsma JB, Bruns DE, 
Gatsonis CA, Glasziou PP, Irwig LM, Lijmer JG, Moher D, Rennie D, de Vet HC; STARD Group. Towards complete and accurate reporting of studies of diagnostic accuracy: The STARD Initiative. Ann Intern Med 2003; 138:40-44.

171. Whiting P, Rutjes AW, Reitsma JB, Bossuyt PM, Kleijnen J. The development of QUADAS: A tool for the quality assessment of studies of diagnostic accuracy included in systematic reviews. BMC Med Res Methodol 2003; 3:25.

172. Liberati A, Altman DG, Tetzlaff J, Mulrow C, Gøtzsche PC, loannidis JP, Clarke M, Devereaux PJ, Kleijnen J, Moher D. The PRISMA statement for reporting systematic reviews and meta-analyses of studies that evaluate health care interventions: Explanation and elaboration. Ann Intern Med 2009; 151:W65-W94.

173. Whiting PF, Rutjes AW, Westwood ME, Mallett S, Deeks JJ, Reitsma JB, Leeflang MM, Sterne JA, Bossuyt PM; QUADAS-2 Group. QUADAS-2: A revised tool for the quality assessment of diagnostic accuracy studies. Ann Intern Med 2011; 155:529536.

174. Schünemann HJ, Oxman AD, Brozek J, Glasziou P, Jaeschke R, Vist GE, Williams JW Jr, Kunz R, Craig J, Montori VM, Bossuyt P, Guyatt GH, GRADE Working Group. Grading quality of evidence and strength of recommendations for diagnostic tests and strategies. BMJ 2008; 336:1106-1110.

175. Deeks Jj. Systematic reviews in health care: Systematic reviews of evaluations of diagnostic and screening tests. BMJ 2001; 323:157-162.

176. Mulrow C, Linn WD, Gaul MK, Pugh JA. Assessing quality of a diagnostic test evaluation. J Gen Intern Med 1989; 4:288295.

177. Bossuyt PM, Lijmer JG, Mol BW. Randomised comparisons of medical tests: Sometimes invalid, not always efficient. Lancet 2000; 356:1844-1847.

178. Lord SJ, Irwig L, Simes RJ. When is measuring sensitivity and specificity sufficient to evaluate a diagnostic test, and when do we need randomized trials? Ann Intern Med 2006; 144:850-855.

179. Chou R, Huffman L. Guideline for the Evaluation and Management of Low Back Pain: Evidence Review. American Pain Society, Glenview, IL, 2009.

www.ampainsoc.org/pub/pdf/LBPEvidRev.pdf

180. Saal JS. General principles of diagnostic testing as related to painful lumbar spine disorders. Spine (Phila Pa 1976) 2002; 27:2538-2545.

181. Manchikanti L, Falco FJE, Boswell MV, Hirsch JA. Facts, fallacies, and politics of comparative effectiveness research: Part 1. Basic considerations. Pain Physician 2010; 13:E23-E54.

182. Manchikanti L, Falco FJE, Boswell MV, Hirsch JA. Facts, fallacies, and politics of comparative effectiveness research: Part 2. Implications for interventional pain management. Pain Physician 2010; 13:E55-E79.

183. Chou R, Atlas SJ, Loeser JD, Rosenquist RW, Stanos SP. Guideline warfare over interventional therapies for low back pain: Can we raise the level of discourse? J Pain 2011; 12:833-839.

184. Manchikanti L, Benyamin RM, Falco FJE, Caraway DL, Datta S, Hirsch JA. Guidelines warfare over interventional techniques: Is there a lack of discourse or straw man? Pain Physician 2012; 15:E1E26.

185. Gemmell H, Miller P. Interexaminer reliability of multidimensional examination regimens used for detecting spinal manipulable lesions: A systematic review. Clin Chiropractic 2005; 8:199-204.

186. Hestboek L, Leboeuf-Yde C. Are chiropractic tests for the lumbo-pelvic spine reliable and valid? A systematic critical literature review. J Manipulative Physiol Ther 2000; 23:258-275.

187. Hollerwoger D. Methodological quality and outcomes of studies addressing manual cervical spine examinations: A review. Man Ther 2006; 11:93-98.

188. May S, Littlewook C, Bishop A. Reliability of procedures used in the physical examination of non-specific low back pain: A systematic review. Aust J Physiother 2006; 52:91-102.

189. Stochkendahl MJ, Christensen HW, Hartvigsen J, Vach W, Haas M, Hestbaek L, Adams A, Bronfort G. Manual examination of the spine: $A$ systematic critical literature review of reproducibility.] Manipulative Physiol Ther 2006; 29:475-485, 485.e1-10.

190. van Trijffel E, Anderegg Q, Bossuyt PM, Lucas C. Inter-examiner reliability of passive assessment of intervertebral motion in the cervical and lumbar spine: A systematic review. Man Ther 2005; 10:256-269.

191. van Tulder M, Furlan A, Bombardier C, Bouter L; Editorial Board of the Cochrane Collaboration Back Review Group. Updated method guidelines for systematic reviews in the Cochrane Collaboration Back Review Group. Spine (Phila Pa 1976) 2003; 28:1290-1299.

192. Staal JB, de Bie R, de Vet HC, Hildebrandt J, Nelemans P. Injection therapy for subacute and chronic low-back pain. Cochrane Database Syst Rev 2008; 3:CDoo1824.

193. Harbord R, Higgins J. METAREG: Stata module to perform meta-analysis regression. Boston College Department of Economics, Boston, MA. http://econpapers.repec.org/software/bocbocode/ S446201.htm

194. Harris RP, Helfand M, Woolf SH, Lohr KN, Mulrow CD, Teutsch SM, Atkins D; Methods Work Group, Third US Preventive Services Task Force. Current methods of the US Preventive Services Task Force. Am J Prevent Med 2001; 20:21-35.

195. Chou R, Huffman L. Use of Chronic Opioid Therapy in Chronic Noncancer Pain: Evidence Review. American Pain Society; Glenview, IL: 2009.

www.ampainsoc.org/library/pdf/Opioid_Final_Evidence_Report.pdf

196. Simopoulos TT, Manchikanti L, Singh V, Gupta S, Hameed H, Diwan S, Cohen SP. A systematic evaluation of prevalence and diagnostic accuracy of sacroiliac joint interventions. Pain Physician 2012; 15:Е305-E344.

197. Atluri S, Singh V, Datta S, Geffert S, Sehgal N, Falco FJE. Diagnostic accuracy of thoracic facet joint nerve blocks: An update of the assessment of evidence. Pain Physician 2012; 15:E483-E496.

198. Falco FJE, Manchikanti L, Datta S, Sehgal N, Geffert S, Onyewu O, Singh V, Bryce DA, Benyamin RM, Simopoulos TT, Vallejo R, Gupta S, Ward SP, Hirsch JA. An update of systematic assessment of diagnostic accuracy of lumbar facet joint nerve blocks. Pain Physician 2012; 15:E868-E9o8.

199. Singh V, Manchikanti L, Onyewu O, Benyamin RM, Datta S, Geffert S, Parr AT, Falco FJE. An update of appraisal of accuracy of thoracic discography as a diagnostic test for chronic spinal pain. Pain Physician 2012; 15:E757-E775.

200. Manchikanti L, Benyamin RM, Singh V, Falco FJE, Hameed H, Derby R, Wolfer LR, Helm II S, Calodney AK, Datta S, Snook LT, Caraway DL, Hirsch JA, Cohen SP. An update of systematic appraisal of accuracy of utility of lumbar discography in chronic low back pain. Pain Physician 2012; In Press.

201. Onyewu O, Manchikanti L, Singh V, Gef- 
fert S, Helm II S, Hameed M, Falco FJE. An update of appraisal of accuracy and utility of cervical discography in chronic neck pain. Pain Physician 2012;15:E777E806.

202. Simopoulos TT, Manchikanti L, Singh V, Gupta S, Hameed H, Diwan S, Cohen SP. A systematic evaluation of prevalence and diagnostic accuracy of sacroiliac joint interventions. Pain Physician 2012; 15:E305-E344.

203. Atluri S, Singh V, Datta S, Geffert S, Sehgal N, Falco FJE. Diagnostic accuracy of thoracic facet joint nerve blocks: An update of the assessment of evidence. Pain Physician 2012; 15:E483-E496.

204. Bogduk N, Aprill C. On the nature of neck pain, discography and cervical zygapophysial joint blocks. Pain 1993; 54:213-217.

205. Wasan AD, Jamison RN, Pham L, Tipirneni N, Nedeljkovic SS, Katz JN. Psychopathology predicts the outcome of medial branch blocks with corticosteroid for chronic axial low back or cervical pain: A prospective cohort study. BMC Musculoskelet Disord 2009; 10:22.

206. Cohen SP, Strassels SA, Kurihara C, Forsythe A, Buckenmaier CC 3rd, McLean B, Riedy G, Seltzer S. Randomized study assessing the accuracy of cervical facet joint nerve (medial branch) blocks using different injectate volumes. Anesthesiology 2010; 112:144-152.

207. Cohen SP, Bajwa ZH, Kraemer JJ, Dragovich A, Williams KA, Stream J, Sireci A, McKnight G, Hurley RW. Factors predicting success and failure for cervical facet radiofrequency denervation: A multi-center analysis. Reg Anesth Pain Med 2007; 32:495-503.

208. Manchikanti L, Pampati V, Damron KS, McManus CD, Jackson SD, Barnhill RC, Martin JC. A randomized, prospective, double-blind, placebo-controlled evaluation of the effect of sedation on diagnostic validity of cervical facet joint pain. Pain Physician 2004; 7:301-309.

209. Manchikanti L, Pampati V, Damron KS, McManus CD, Jackson SD, Barnhill RC Martin JC. The effect of sedation on diagnostic validity of facet joint nerve blocks: An evaluation to assess similarities in population with involvement in cervical and lumbar regions (ISRCTNo: 76376497). Pain Physician 2006; 9:47-52.

210. Manchikanti L, Boswell MV, Manchukonda R, Cash KA, Giordano J. Influence of prior opioid exposure on diagnostic facet joint nerve blocks. J Opioid Manage
2008; 4:351-360.

211. Scanlon GC, Moeller-Bertram T, Romanowsky SM, Wallace MS. Cervical transforaminal epidural steroid injections. More dangerous than we think? Spine (Phila Pa 1976) 2007; 32:1249-1256.

212. Magee $M$, Kannangara $S$, Dennien $B$, Lonergan R, Emmett L, Van der Wall $\mathrm{H}$. Paraspinal abscess complicating facet joint injection. Clin Nucl Med 2000; 25:71-73.

213. Marks RC, Semple AJ. Spinal anaesthesia after facet joint injection. Anaesthesia 1988; 43:65-66.

214. Kim SY, Han SH, Jung MW, Hong JH. Generalized infection following facet joint injection -A case report-. Korean J Anesthesiol 2010; 58:401-404.

215. Ghosh PS, Loddenkemper T, Blanco MB, Marks M, Sabella C, Ghosh D. Holocord spinal epidural abscess. J Child Neurol 2009; 24:768-771.

216. Hoelzer BC, Weingarten TN, Hooten WM, Wright RS, Wilson WR, Wilson PR. Paraspinal abscess complicated by endocarditis following a facet joint injection. Eur J Pain 2008; 12:261-265.

217. Park MS, Moon SH, Hahn SB, Lee HM. Paraspinal abscess communicated with epidural abscess after extra-articular facet joint injection. Yonsei Med J 2007; 48:711-714.

218. Weingarten TN, Hooten WM, Huntoon MA. Septic facet joint arthritis after a corticosteroid facet injection. Pain Med 2006; 7:52-56.

219. Dizdar O, Alyamaç E, Onal IK, Uzun O. Group B streptococcal facet joint arthritis: case report. Spine (Phila Pa 1976) 2005; 30:E414-E416.

220. Lima RM, Navarro LH, Carness JM, Bar$\operatorname{ros} \mathrm{GA}$, Marques ME, Solanki D, Ganem EM. Clinical and histological effects of the intrathecal administration of methylprednisolone in dogs. Pain Physician 2010; 13:493-501.

221. Kapoor R, Liu J, Devasenapathy A, Gordin V. Gadolinium encephalopathy after intrathecal gadolinium injection. Pain Physician 2010; 13:E321-E326.

222. Kim KH, Choi SH, Shin SW, Kim CH, Kim JI. Cervical facet joint injections in the neck and shoulder pain. J Korean Med Sci 2005; 20:659-662.

223. Weinstein RS. Glucocorticoid-induced bone disease. New Engl ] Med 2011; 365:62-70.

224. Folman Y, Livshitz A, Shabat S, Gepstein R. Relief of chronic cervical pain after se- lective blockade of zygapophyseal joint. Harefuah 2004; 143:339-341, 391.

225. Heckmann JG, Maihofner C, Lanz S, Rauch C, Neundorfer B. Transient tetraplegia after cervical facet joint injection for chronic neck pain administered without imaging guidance. Clin Neurol Neurosurg 2006; 108:709-711.

226. Manchikanti L, Cash KA, Moss TL, Pampati $V$. Effectiveness of protective measures in reducing risk of radiation exposure in interventional pain management: a prospective evaluation. Pain Physician 2003; 6:301-305.

227. Manchikanti L, Cash KA, Moss TL, Pampati $V$. Radiation exposure to the physician in interventional pain management. Pain Physician 2002; 5:385-393.

228. Manchikanti L, Cash K, Moss T, Rivera J, Pampati V. Risk of whole body radiation exposure and protective measures in fluoroscopically guided interventional techniques: A prospective evaluation. BMC Anesthesiol 2003; 3:2.

229. Manchikanti L. Role of neuraxial steroids in interventional pain management. Pain Physician 2002; 5:182-199.

230. Manchikanti L, Pampati V, Beyer C, Damron KS, Cash KA, Moss TL. The effect of neuraxial steroids on weight and bone mass density: A prospective evaluation. Pain Physician 2000; 3:357-366.

231. Okada K. Studies on the cervical facet joints using arthrography of the cervical facet joint. J Jpn Orthop Assoc 1981; 55:563-580.

232. Sebesta P, Stulík J, Kryl J, Vyskocil T. Purulent arthritis of the spinal facet joint. Acta Chir Orthop Traumatol Cech 2005; 72:387-389.

233. Takeno K, Kobayashi S, Miyazaki T, Shimada S, Kubota M, Meir A, Urban J, Baba $\mathrm{H}$. Lidocaine cytotoxicity to the zygapophysial joints in rabbits: Changes in cell viability and proteoglycan metabolism in vitro. Spine (Phila Pa 1976) 2009; 34:E945-E951.

234. Alcock E, Regaard A, Browne J. Facet joint injection: A rare form cause of epidural abscess formation. Pain 2003; 103:209-210.

235. Dayer MJ, Gransden W, Goldsmith DJ. Facet joint osteomyelitis in a patient on long-term hemodialysis. Am J Kidney Dis 2000; 36:1041-1044.

236. Bouchez B, Arnott G, Delfosse JM. Acute spinal epidural abscess. J Neurol 1985; 231:343-344.

237. Cook NJ, Hanrahan P, Song S. Paraspinal abscess following facet joint injec- 
tion. Clin Rheumatol 1999; 18:52-53.

238. Verrills $P$, Mitchell $B$, Vivian $D$, Nowesenitz G, Lovell B, Sinclair C. The incidence of intravascular penetration in medial branch blocks: Cervical, thoracic, and lumbar spines. Spine (Phila Pa 1976) 2008; 33:E174-E177.

239. Edlow BL, Wainger BJ, Frosch MP, Copen WA, Rathmell JP, Rost NS: Posterior circulation stroke after $\mathrm{C}_{1}-\mathrm{C}_{2}$ intraarticular facet steroid injection: Evidence for diffuse microvascular injury. Anesthesiology 2010; 112:1532-1535.

240. Manchikanti L, Malla Y, Wargo BW, Cash KA, Pampati V, Fellows B. Complications of fluoroscopically directed facet joint nerve blocks: A prospective evaluation of 7,500 episodes with 43,000 nerve blocks. Pain Physician 2012; 15:E143-E150.

241. Manchikanti L, Malla Y, Wargo BW, Fellows B. Infection control practices (safe injection and medication vial utilization) for interventional techniques: Are they based on relative risk management or evidence? Pain Physician 2011; 14:425434 .

242. Manchikanti L, Malla Y, Wargo BW, Cash KA, McManus CD, Damron KS, Jackson SD, Pampati V, Fellows B. A prospective evaluation of bleeding risk of interventional techniques in chronic pain. Pain Physician 2011; 14:317-329.

243. Manchikanti L, Malla Y, Wargo BW, Fellows B. Preoperative fasting before interventional techniques: Is it necessary or evidence-based? Pain Physician 2011; 14:459-467.

244. Datta S, Manchikanti L. It is time to abandon atlanto-axial joint injections: Do no harm! Anesthesiology 2011; 114:222-224.

245. Barnsley L, Lord S, Bogduk N. Comparative local anesthetic blocks in the diagnosis of cervical zygapophysial joints pain. Pain 1993; 55:99-106.

246. Lord SM, Barnsley L, Bogduk N. The utility of comparative local anesthetic blocks versus placebo-controlled blocks for the diagnosis of cervical zygapophysial joint pain. Clin J Pain 1995; 11:208213.

247. Reid MC, Lachs MS, Feinstein AR. Use of methodological standards in diagnostic test research. Getting better but still not good. JAMA 1995; 274:645-651.

248. Guyatt GH, Oxman AD, Kunz R, FalckYtter Y, Vist GE, Liberati A, Schünemann HJ, GRADE Working Group. Going from evidence to recommendations. BM] 2008; 336:1049-1051.
249. Guyatt GH, Oxman AD, Kunz R, Vist GE, Falck-Ytter Y, Schünemann HJ, GRADE Working Group. What is "quality of evidence" and why is it important to clinicians? BMJ 2008, 336:995-998.

250. Louhiala P, Puustinen R. Rethinking the placebo effect.] Med Ethics 2008; 34:107109.

251. Louhiala P. The ethics of the placebo in clinical practice revisited. J Med Ethics 2009; 35:407-409.

252. Quill TE, Holloway RG. Evidence, preferences, recommendations--finding the right balance in patient care. $N$ Engl J Med 2012; 366:1653-1655.

253. Gelijns AC, Gabriel SE. Looking beyond translation--integrating clinical research with medical practice. $N$ Engl J Med 2012; 366:1659-1661.

254. Blease C. The principle of parity: The "placebo effect" and physician communication. J Med Ethics 2012; 38:199-203.

255. Häuser W, Bartram C, Bartram-Wunn $\mathrm{E}$, Tölle T. Adverse events attributable to nocebo in randomized controlled drug trials in fibromyalgia syndrome and painful diabetic peripheral neuropathy: Systematic review. Clin J Pain 2012; 28:437-451.

256. Lyby PS, Forsberg JT, Asli O, Flaten MA. Induced fear reduces the effectiveness of a placebo intervention on pain. Pain 2012; 153:1114-1121.

257. Manchikanti L, Pampati V, Damron KS. The role of placebo and nocebo effects of perioperative administration of sedatives and opioids in interventional pain management. Pain Physician 2005; 8:349-355.

258. Manchikanti L, Giordano J, Fellows B, Hirsch JA. Placebo and nocebo in interventional pain management: $A$ friend or a foe - or simply foes? Pain Physician 2011; 14:E157-E175.

259. Iversen T, Solberg TK, Romner B, Wilsgaard T, Twisk J, Anke A, Nygaard O, Hasvold T, Ingebrigtsen T. Effect of caudal epidural steroid or saline injection in chronic lumbar radiculopathy: Multicentre, blinded, randomised controlled trial. BM] 2011; 343:d 5278 .

26o. Carette $S$, Marcoux S, Truchon R, Grondin C, Gagnon J, Allard Y, Latulippe M. A controlled trial of corticosteroid injections into facet joints for chronic low back pain. N Engl J Med 1991; 325:10021007.

261. Carette S, Leclaire R, Marcoux S, Morin F, Blaise GA, St-Pierre A, Truchon R,
Parent $F$, Levesque J, Bergeron $\mathrm{V}$, Montminy $P$, Blanchette $C$. Epidural corticosteroid injections for sciatica due to herniated nucleus pulposus. $N$ Engl J Med 1997; 336:1634-1640.

262. Indahl A, Kaigle A, Reikerås $O$, Holm S. Electromyographic response of the porcine multifidus musculature after nerve stimulation. Spine (Phila Pa 1976) 1995; 20:2652-2658.

263. Indahl A, Kaigle AM, Reikeräs $\mathrm{O}$, Holm $\mathrm{SH}$. Interaction between the porcine lumbar intervertebral disc, zygapophysial joints, and paraspinal muscles. Spine (Phila Pa 1976) 1997; 22:2834-2840.

264. Pham Dang C, Lelong A, Guilley J, Nguyen JM, Volteau C, Venet G, Perrier C, Lejus C, Blanloeil Y. Effect on neurostimulation of injectates used for perineural space expansion before placement of a stimulating catheter: Normal saline versus dextrose $5 \%$ in water. Reg Anesth Pain Med 2009; 34:398-403.

265. Tsui BC, Kropelin B, Ganapathy S, Finucane B. Dextrose $5 \%$ in water: Fluid medium maintaining electrical stimulation of peripheral nerve during stimulating catheter placement. Acta Anaesthesiol Scand 2005; 49:1562-1565.

266. Kang YM, Choi WS, Pickar JG. Electrophysiologic evidence for an intersegmental reflex pathway between lumbar paraspinal tissues. Spine (Phila Pa 1976) 2002; 27:E56-E63.

267. Pasqualucci A, Varrassi G, Braschi A, Peduto VA, Brunelli A, Marinangeli $F$, Gori F, Colò F, Paladini A, Mojoli F. Epidural local anesthetic plus corticosteroid for the treatment of cervical brachial radicular pain: single injection versus continuous infusion. Clin J Pain 2007; 23:551-557.

268. Lavoie PA, Khazen T, Filion PR. Mechanisms of the inhibition of fast axonal transport by local anesthetics. Neuropharmacology 1989; 28:175-181.

269. Bisby MA. Inhibition of axonal transport in nerves chronically treated with local anesthetics. Exp Neurol 1975; 47:481-489.

270. Katz WA, Rothenberg R. Section 3: The nature of pain: pathophysiology. J Clin Rheumatol 2005; 11:S11-S15.

271. Cassuto J, Sinclair R, Bonderovic M. Anti-inflammatory properties of local anesthetics and their present and potential clinical implications. Acta Anaesthesiol Scand 2006; 50:265-282.

272. Arnér S, Lindblom U, Meyerson BA, Molander C. Prolonged relief of neuralgia after regional anesthetic blocks. A call 
for further experimental and systematic clinical studies. Pain 1990; 43:287-297.

273. Melzack R, Coderre TJ, Katz J, Vaccarino AL. Central neuroplasticity and pathological pain. Ann N Y Acad Sci 2001; 933:157-174.

274. Sato C, Sakai A, Ikeda Y, Suzuki H, Sakamoto $A$. The prolonged analgesic effect of epidural ropivacaine in a rat model of neuropathic pain. Anesth Analg 2008; 106:313-320.

275. Tachihara H, Sekiguchi M, Kikuchi S, Konno S. Do corticosteroids produce additional benefit in nerve root infiltration for lumbar disc herniation. Spine (Phila Pa 1976) 2008; 33:743-747.

276. Manchikanti L, Singh V, Falco FJE, Cash KA, Pampati V. Evaluation of lumbar facet joint nerve blocks in managing chronic low back pain: A randomized, doubleblind, controlled trial with a 2-year follow-up. Int J Med Sci 2010; 7:124-135.

277. Manchikanti L, Cash KA, McManus CD, Pampati $\mathrm{V}$, Benyamin RM. A preliminary report of a randomized double-blind, active controlled trial of fluoroscopic thoracic interlaminar epidural injections in managing chronic thoracic pain. Pain Physician 2010; 13:E357-E369.

278. Manchikanti L, Cash KA, McManus CD, Pampati V, Smith HS. One year results of a randomized, double-blind, active controlled trial of fluoroscopic caudal epidural injections with or without steroids in managing chronic discogenic low back pain without disc herniation or radiculitis. Pain Physician 2011; 14:25-36.

279. Manchikanti L, Cash KA, McManus CD, Pampati V, Benyamin RM. Preliminary results of a randomized, double-blind, controlled trial of fluoroscopic lumbar interlaminar epidural injections in managing chronic lumbar discogenic pain without disc herniation or radiculitis. Pain Physician 2010; 13:E279-E292.

280. Manchikanti L, Cash KA, Pampati V, Wargo BW, Malla Y. Cervical epidural injections in chronic discogenic neck pain without disc herniation or radiculitis: Preliminary results of a randomized, double-blind, controlled trial. Pain Physician 2010; 13:E265-E278.

281. Manchikanti L, Singh V, Cash KA, Pampati V, Damron KS, Boswell MV. A randomized, controlled, double-blind trial of fluoroscopic caudal epidural injec- tions in the treatment of lumbar disc herniation and radiculitis. Spine (Phila Pa 1976) 2011; 36:1897-1905.

282. Manchikanti L, Singh V, Falco FJE, Cash KA, Pampati V. Evaluation of the effectiveness of lumbar interlaminar epidural injections in managing chronic pain of lumbar disc herniation or radiculitis: A randomized, double-blind, controlled trial. Pain Physician 2010; 13:343-355.

283. Manchikanti L, Cash KA, Pampati V, Wargo BW, Malla Y. The effectiveness of fluoroscopic cervical interlaminar epidural injections in managing chronic cervical disc herniation and radiculitis: Preliminary results of a randomized, double-blind, controlled trial. Pain Physician 2010; 13:223-236.

284. Manchikanti L, Singh V, Cash KA, Datta $S$. Management of pain of post lumbar surgery syndrome: One-year results of a randomized, double-blind, active controlled trial of fluoroscopic caudal epidural injections. Pain Physician 2010; 13:509-521.

285. Manchikanti L, Singh V, Falco FJE, Cash KA, Pampati V, Fellows B. Comparative effectiveness of a one-year follow-up of thoracic medial branch blocks in management of chronic thoracic pain: A randomized, double-blind active controlled trial. Pain Physician 2010; 13:535-548.

286. Manchikanti L, Pampati V, Cash KA. Protocol for evaluation of the comparative effectiveness of percutaneous adhesiolysis and caudal epidural steroid injections in low back and/or lower extremity pain without post surgery syndrome or spinal stenosis. Pain Physician 2010; 13:E91-E110.

287. Hayashi N, Weinstein JN, Meller ST, Lee HM, Spratt KF, Gebhart GF. The effect of epidural injection of betamethasone or bupivacaine in a rat model of lumbar radiculopathy. Spine (Phila Pa 1976) 1998; 23:877-885

288. Lee HM, Weinstein JN, Meller ST, Hayashi N, Spratt KF, Gebhart GF. The role of steroids and their effects on phospholipase A2. An animal model of radiculopathy. Spine (Phila Pa 1976) 1998; 23:1191-1196.

289. Johansson A, Hao J, Sjölund B. Local corticosteroid application blocks transmission in normal nociceptive C-fibres. Acta Anaesthesiol Scand 1990; 34:335-338.
290. Grigoras A, Lee P, Sattar F, Shorten G. Perioperative intravenous lidocaine decreases the incidence of persistent pain after breast surgery. Clin J Pain 2012; 28:567-572.

291. Cui W, Li Y, Li S, Wang R, Li J. Systemic administration of lidocaine reduces morphine requirements and postoperative pain of patients undergoing thoracic surgery after propofol-remifentanil based anaesthesia. Eur J Anaesthesiol 2010; 27:41-46.

292. Koppert W, Zeck S, Sittl R. Low dose lidocaine suppresses experimentally induced hyperalgesia in humans. Anesthesiology 1998; 89:1345-1353.

293. Koppert W, Ostermaier N, Sittl R, Weidner C, Schmelz M. Low dose lidocaine reduces secondary hyperalgesia by a central mode of action. Pain 2000; 85:217-224.

294. Kawamata M, Takahashi T, Kozuka Y, Nawa $Y$, Nishikawa K, Narimatsu E, Watanabe $\mathrm{H}$, Namiki A. Experimental incision induced pain in human skin: effects of systemic lidocaine on flare formation and hyperalgesia. Pain 2002; 100:77-89.

295. Hollmann MW, Durieux M. Local anesthetics and the inflammatory response. Anesthesiology 2000; 93:858-875

296. Sugimoto M, Uchida I, Mashimoto T. Local anaesthetics have different mechanisms and sites of action at the recombinant NMDA receptors. $\mathrm{Br}$ J Pharmacol 2003; 138:876-882.

297. Arner S, Lindblom U, Meyerson BA, Molander $C$. Prolonged relief of neuralgia after regional anesthetic block. A call for further experimental and systematic clinical studies. Pain 1990; 43:287-297.

298. Pasqualucci A. Experimental and clinical studies about the preemptive analgesia with local anesthetics. Possible reasons of the failure. Minerva Anestesiol 1998; 64:445-457.

299. Bonica JJ, Buckley FP. Regional analgesia with local anesthetics. In: Bonica JJ (ed). The Management of Pain. Lea \& Febiger, Philadelphia, 1990, pp 1883-1966.

300. Manchikanti L, Singh V. Are the results of a multicenter analysis of radiofrequency denervation success as a function of single diagnostic block reliable? Spine J 2009; 9:704-705. 